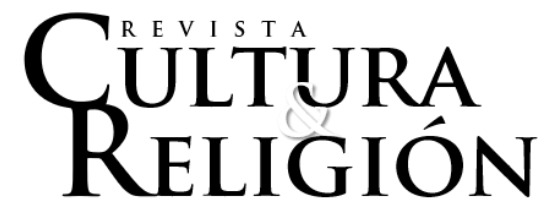

Vol. XV, No 2 (2021) pp. 167-209

Recibido: 31 de julio de 2020

Aceptado: 30 de marzo de 2021

\title{
DE MILAGROS, IMÁGENES Y SANTUARIOS: APROPIACIONES SIMBÓLICAS EN TRES CULTOS CATÓLICOS SUDAMERICANOS
}

\begin{abstract}
About miracles, images and shrines: symbolic appropriations in three southamerican catolic worships
\end{abstract}

\author{
Julia Costilla* \\ Universidad de Buenos Aires, Argentina \\ ORCID: 0000-0002-4424-2576
}

\section{Resumen}

Este trabajo presenta un análisis antropológico sobre imágenes católicas milagrosas, partiendo de una investigación comparativa y de larga duración sobre tres santuarios sudamericanos: dos de origen colonial, el de la Virgen de Copacabana (Bolivia) y el del Señor de los Milagros de Lima (Perú), y el más reciente de la Virgen del Rosario de San Nicolás (Argentina). Siguiendo lineamientos conceptuales de la antropología simbólica y a través de una indagación histórico-etnográfica, con documentos de archivo y trabajo de campo, se analiza cómo se construyen simbologías sagradas y las apropiaciones movilizadas en torno a ellas. Se afirma en este artículo que en los tres cultos las simbologías centrales se manifiestan como una entidad tripartita: imagen/ milagro/ santuario, y que en cada caso se expresó con mayor peso uno de esos tres aspectos. Se definen significados comunes a las tres simbologías y se

\footnotetext{
* Investigadora de CONICET en el Instituto de Ciencias Antropológicas de la Universidad de Buenos Aires (UBA). Docente de la carrera de Ciencias Antropológicas, Facultad de Filosofía y Letras, UBA. Correo electrónico: juliacostilla@hotmail.com
} 
plantea que sus historias dan cuenta de cinco modalidades de apropiación -de empleo e interpretación- de tales símbolos: 1) evangelizadora/civilizadora; 2) devocional; 3) político-eclesiástica; 4) sociopolítica; 5) económica. De esta manera, se propone un modelo para el estudio antropológico de santuarios católicos que pueda ser utilizado y contrastado empíricamente en investigaciones sobre cultos similares.

Palabras clave: santuarios católicos, imágenes milagrosas, símbolo religioso, historia hispanoamericana, antropología simbólica.

\section{Abstract}

This paper presents an anthropological analysis about miraculous catholic images, beginning with a comparative and longue durée investigation of three South American sanctuaries: Our Lady of Copacabana (Bolivia) and Lord of Miracles (Peru), with colonial origins, and the contemporaneous Lady of the Rosary of San Nicolás (Argentina). Following the symbolic anthropology conceptual guidelines, and implementing a historic-ethnographic inquiry, based on archive documents and fieldwork, I will analyze how sacred symbologies are constructed and which are the appropriations mobilized around them. I claim that the three cult's central symbologies manifest a tripartite entity: image/ miracle/ sanctuary, and that these aspects had different weights in each worship. I also define shared meanings on three symbologies and present five symbolic appropriations modalities - uses and interpretations of these symbols- that their histories show: 1) evangelizer/ civilizer; 2) devotional; 3) politicalecclesiastical; 4) sociopolitical; 5) economic. In this way, I propose an anthropological model for catholic shrines studies, a model that similar worships investigations could use and empirically contrast.

Keywords: catholic sanctuaries, miraculous images, religious symbol, Hispano-American history.

Costilla, J. (2021). De milagros, imágenes y santuarios: apropiaciones simbólicas en tres cultos católicos sudamericanos. Revista Cultura y Religión, 15(2), 167-209. 


\section{Introducción}

Si nos cruzamos con un santuario católico en cualquier parte del mundo, lo primero que observaremos es un lugar de culto distinguido en el espacio: ya se trate de un pequeño altar o de una imponente basílica. Allí encontraremos una imagen también distinguida, y posiblemente rodeada de objetos dejados por sus fieles. Si además tenemos oportunidad de conversar con algún fiel (o de leer un testimonio escrito), seguramente vamos a conocer algún milagro que la imagen concedió. Estos elementos se conjugan en la definición de santuario que podemos dar desde las ciencias sociales y en particular desde la antropología histórica: un tipo de ermita distinguida por ser templo de una imagen milagrosa de especial devoción, hacia donde suelen peregrinar personas de distintas poblaciones (Calavia Sáez, 2002; Christian, [1981] 1991; Díez Taboada, 1989; Steil, 2002;). Con estos rasgos, el fenómeno de los santuarios resulta singularmente rico para un estudio desde la antropología interpretativa o simbólica, puesto que los mismos se inscriben dentro de sistemas religiosos, y estos a su vez pueden ser entendidos como sistemas de símbolos culturales (Geertz, 1987; Turner, 1980). Desde esta perspectiva, el objetivo de estas páginas es analizar imágenes milagrosas en santuarios católicos, y de ese modo, indagando en significados nativos y diversas apropiaciones del símbolo, proponer un modelo para el estudio antropológico de este tipo de cultos. Para ello, se parte de una investigación comparativa y de larga duración sobre tres santuarios católicos sudamericanos, realizada en el marco de una tesis doctoral (Costilla, 2014).

De los casos trabajados, el más antiguo es el de la Virgen de Copacabana (Bolivia), una imagen de la Candelaria tallada por un indígena local en 1583. Le sigue el del Señor de los Milagros de Lima (Perú), un mural de Cristo crucificado con más de 360 años de antigüedad, pintado por un africano, según coinciden las fuentes sobre el culto. Por último, se trabajó con

Costilla, J. (2021). De milagros, imágenes y santuarios: apropiaciones simbólicas en tres cultos católicos sudamericanos. Revista Cultura y Religión, 15(2), 167-209. 
la Virgen del Rosario de San Nicolás (Argentina), venerada desde 1983 a partir de un resonado fenómeno de apariciones y mensajes marianos. Con todas sus distancias y diferencias, estos tres cultos permitieron plantear comparaciones y establecer conclusiones respecto a la simbología religiosa en santuarios católicos latinoamericanos.

La metodología empleada combinó el enfoque etnográfico con el análisis histórico, recurriendo a variadas fuentes de información: documentos de archivos eclesiásticos y civiles, crónicas y publicaciones confesionales, notas periodísticas, folletería, registros de campo efectuados entre los años 2008 y 2011 y entrevistas a fieles, sacerdotes, laicos y habitantes de las ciudades involucradas. Este corpus respondió al interés antropológico, diacrónico y comparativo de la investigación (cfr. Braudel, 1953; Costilla, 2016; González Torres, 1982): relevar, para cada caso, diversas $-y$ equiparables- perspectivas nativas en distintos períodos históricos. Por tanto, para este trabajo se procuró seleccionar al menos un testimonio de cada tipo de fuente; y dada la amplitud temporal y espacial, la descripción histórica de los santuarios será apenas esbozada. Aunque en tales condiciones el análisis comparativo plantea desafíos y limitaciones, consideramos necesario trascender, en cierta medida, las épocas y contextos para poder proponer afirmaciones generales sobre el fenómeno de los santuarios.

Si por un lado el estudio comparado de estos cultos aporta al conocimiento sobre la historia y la religiosidad de las localidades donde se desarrollaron, también nos enseña sobre cómo se construyen simbologías sagradas -católicas, en particular- y las diversas apropiaciones que se movilizan en torno a ellas. Esta segunda cuestión será el foco del presente trabajo y nos permitirá proponer un modelo de análisis para el estudio de santuarios católicos. A partir de identificar ciertos aspectos comunes a los casos estudiados, se expondrá cómo la simbología sagrada, en diferentes momentos

Costilla, J. (2021). De milagros, imágenes y santuarios: apropiaciones simbólicas en tres cultos católicos sudamericanos. Revista Cultura y Religión, 15(2), 167-209. 
históricos, ha sido apropiada por distintos actores y desde intereses que exceden el plano religioso.

En un primer apartado se sintetizarán los aportes de la tesis que dio lugar a este trabajo, necesarios para enmarcar y comprender el análisis posterior. Los santuarios católicos que constituyeron los referentes empíricos serán contextualizados y se describirán sus trayectorias históricas -reconstruidas en la investigación-, para luego plantear tres afirmaciones generales elaboradas a partir de interpretar esas historias desde la antropología simbólica. El segundo apartado desarrollará las apropiaciones registradas en distintos contextos, siguiendo una clasificación operativa y transversal a los tres cultos.

\section{Santuarios católicos latinoamericanos y símbologías sagradas: planteos iniciales y premisas de trabajo}

La evangelización de América, paralela al proceso de conquista y colonización, dio lugar al surgimiento de numerosos santuarios católicos. En esto fueron decisivas las disposiciones del Concilio de Trento (1562-1565) incorporadas luego en los concilios indianos- por el papel central que le otorgaron a las imágenes y a la proliferación de sucesos prodigiosos y ejemplares, en tanto poderosas representaciones del mensaje cristiano para las poblaciones nativas (Acosta Luna, 2011; Bouysse-Cassagne, 1997; Gisbert, Gruzinski, Rostworowski y Estenssoro cit. en Costilla, 2014; entre otros). Dos de los santuarios originados en este período colonial son el de la Virgen de Copacabana, en la localidad homónima dentro del altiplano boliviano, y el del Señor de los Milagros de la ciudad de Lima, en Perú.

En un contexto posterior, tras el período emancipatorio y la formación de los Estados republicanos, la Iglesia católica continuó su tarea evangelizadora en América dentro de renovadas condiciones: la reformulación del antiguo patronato regio, la progresiva separación entre las esferas estatal y religiosa, y

Costilla, J. (2021). De milagros, imágenes y santuarios: apropiaciones simbólicas en tres cultos católicos sudamericanos. Revista Cultura y Religión, 15(2), 167-209. 
la centralización o "romanización" del cuerpo institucional de la Iglesia. A grandes rasgos, su objetivo pasó a ser el de "reconquistar" la sociedad dentro de los espacios diocesanos tradicionales y expandir la cristiandad hacia los márgenes de los Estados nacionales (Di Stéfano y Zanatta, 2000; Nicoletti, 2012). En esos marcos surgieron nuevos cultos vinculados a santuarios: entre ellos, se destaca el de la Virgen del Rosario de San Nicolás por su tardío origen, a fines del siglo XX, y la cantidad de peregrinos que congrega anualmente alrededor de quinientos mil. A continuación, se presentan brevemente las historias de los tres cultos, cada uno con su respectivo santuario.

La imagen de la Virgen de Copacabana fue tallada en 1582 por un descendiente de la elite incaica, nativo del pueblo de indios de Copacabana. Según los documentos más antiguos, se trata de una imagen de la Virgen de la Candelaria (advocación española) que, debido a una serie de manifestaciones milagrosas reconocidas por autoridades nativas y coloniales, fue entronizada en dicho pueblo en el año 1583 (Costilla, 2010). La devoción por esta Virgen, ligada a su fama de milagrosa, dio lugar a un destacado santuario cuyo emplazamiento, a orillas del Lago Titicaca, debe entenderse en conexión con la religiosidad prehispánica: Copacabana era un lugar central dentro de la geografía sagrada andina, reconocido por ser foco de peregrinaciones ya desde épocas preincaicas (Costilla, 2010; Salles-Reese, 1997). El santuario católico fue consolidado durante el siglo XVII, a cargo de frailes agustinos, y mantuvo su vigencia durante toda la transición al período republicano -con cambios en su administración, encargada a los franciscanos desde 1840. En 1940, el templo fue declarado basílica y hasta el día de hoy continúa congregando a numerosos peregrinos para sus festividades anuales (los días 2 de febrero y 6 de agosto), principalmente de Bolivia y Perú (ver Figura $\mathrm{N}^{\circ} 1$ ). Al mismo tiempo, la Virgen fue coronada en el año 1925 y convertida en patrona simbólica de Bolivia, lo cual la volvió un referente identitario clave para la colectividad de migrantes (Costilla, 2014).

Costilla, J. (2021). De milagros, imágenes y santuarios: apropiaciones simbólicas en tres cultos católicos sudamericanos. Revista Cultura y Religión, 15(2), 167-209. 
Figura $\mathbf{N}^{\circ}$ 1: Imagen procesional de la Virgen de Copacabana en la entrada del santuario

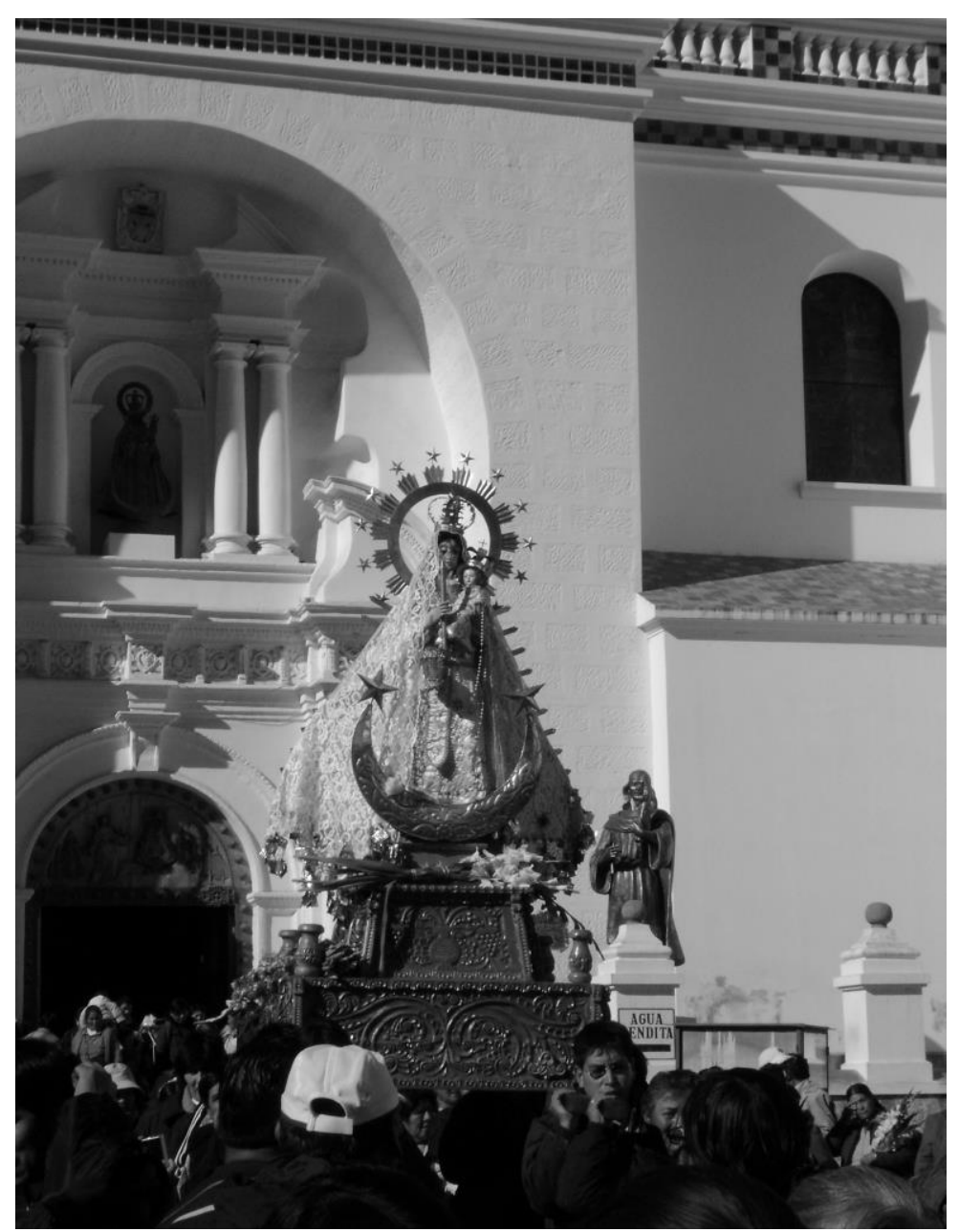

Fuente: Fotografía de la autora, 6 de agosto de 2010.

Con un origen posterior, el culto al Señor de los Milagros se desarrolló en la ciudad de Lima durante el siglo XVII. Según fuentes de la época, un grupo de angoleños, que habitaban en el barrio limeño de Pachacamilla, comenzaron a venerar una imagen mural de Cristo crucificado, pintada por uno

Costilla, J. (2021). De milagros, imágenes y santuarios: apropiaciones simbólicas en tres cultos católicos sudamericanos. Revista Cultura y Religión, 15(2), 167-209. 
de ellos en el año 1651 (ver Figura $\mathrm{N}^{\circ}$ 2). Luego de ser reconocida por una serie de milagros, la imagen fue incrementando sus devotos y movilizando la llegada de peregrinos, hasta terminar siendo aceptada por las más altas autoridades coloniales, incluidos el virrey y el arzobispo. Con su culto ya consolidado $-\mathrm{y}$ asignado a una congregación de religiosas-, en 1715 el Cristo de los Milagros fue jurado por el Cabildo de Lima como patrono de la ciudad -en especial como protector contra los sismos, debido a su prodigiosa conservación tras un fuerte terremoto en 1687. Para fines del siglo XVIII se inauguró un nuevo templo y durante la etapa republicana el santuario siguió siendo uno de los principales centros de peregrinación de la ciudad, distinguido además por contar con una importante hermandad de devotos. ${ }^{1}$ Durante el siglo XX, el Señor de los Milagros (de Nazarenas) fue convertido en el principal referente de la peruanidad, reconocido por su vinculación con distintas tradiciones culturales (africanas, católicas e indígenas) y expandido por la colectividad de migrantes peruanos, al tiempo que su procesión anual, cada 18 de octubre, continúa reuniendo a unos 40 mil fieles en torno al santuario (Costilla, 2015, 2011).

\footnotetext{
${ }^{1}$ La Hermandad del Señor de los Milagros, que actualmente congrega a unos cinco mil miembros, es una institución originada en la incipiente cofradía de angoleños de 1650. Esta, en 1687, dio lugar a una hermandad de cargadores, sahumadoras y cantoras, en tanto acompañantes de la imagen procesional del Cristo, y la misma pudo ser oficializada en 1878 (Banchero Castellano, 1972; Hermandad del Señor de los Milagros de Nazarenas, 2017). Paralelamente, desde 1702, el culto quedó a cargo de la congregación de hermanas Nazarenas Carmelitas Descalzas, un beaterio de monjas que funcionaba en la ciudad limeña desde 1683 y que logró convertirse en monasterio en 1730, ya con el santuario consolidado y con las obras de un nuevo templo en marcha (Banchero Castellano, 1972).
}

Costilla, J. (2021). De milagros, imágenes y santuarios: apropiaciones simbólicas en tres cultos católicos sudamericanos. Revista Cultura y Religión, 15(2), 167-209. 
Figura $\mathbf{N}^{\circ}$ 2: Imagen mural del Señor de los Milagros

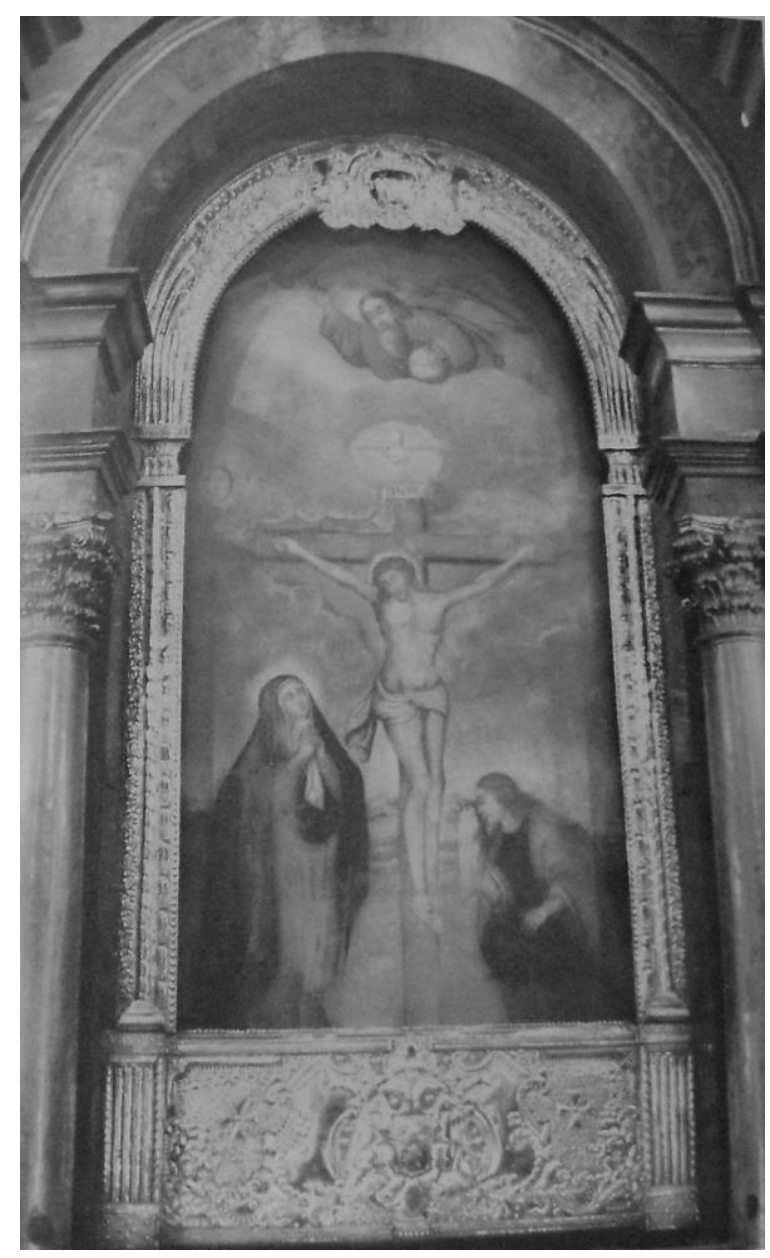

Fuente: Banchero Castellano (1976, p. 113).

El culto más reciente es el desarrollado en torno a la Virgen del Rosario de San Nicolás desde el año 1983 (ver Figura $N^{\circ}$ 3). Originado en un fenómeno de apariciones y mensajes marianos relatados por una vecina de la ciudad -y en el contexto de una fuerte crisis socioeconómica local-, la devoción fue multiplicándose exponencialmente, entre feligreses y peregrinos $\mathrm{Al}$ cabo de tres años, en 1986 se inició una imponente obra para su santuario y se comenzaron a celebrar las primeras procesiones con la imagen. En este caso se trataba de una escultura de la Virgen del Rosario que permanecía guardada en el campanario

Costilla, J. (2021). De milagros, imágenes y santuarios: apropiaciones simbólicas en tres cultos católicos sudamericanos. Revista Cultura y Religión, 15(2), 167-209. 
de la catedral desde hacía décadas (originalmente enviada desde Roma para la iglesia local en el año 1884). Según las autoridades eclesiásticas locales, dicha imagen coincidía con las manifestaciones referidas por la vecina "vidente" y por ese motivo fue reubicada para el culto público. A menos de 25 años de haber sido entronizada en su santuario, la Virgen fue coronada por el obispado en el año 2009 y llegó a congregar unas 700 mil personas para la celebración de su vigésimo quinto aniversario el 25 de septiembre de 2008 (Costilla, 2010).

Figura $\mathbf{N}^{\circ}$ 3: La Virgen de San Nicolás en un periódico local

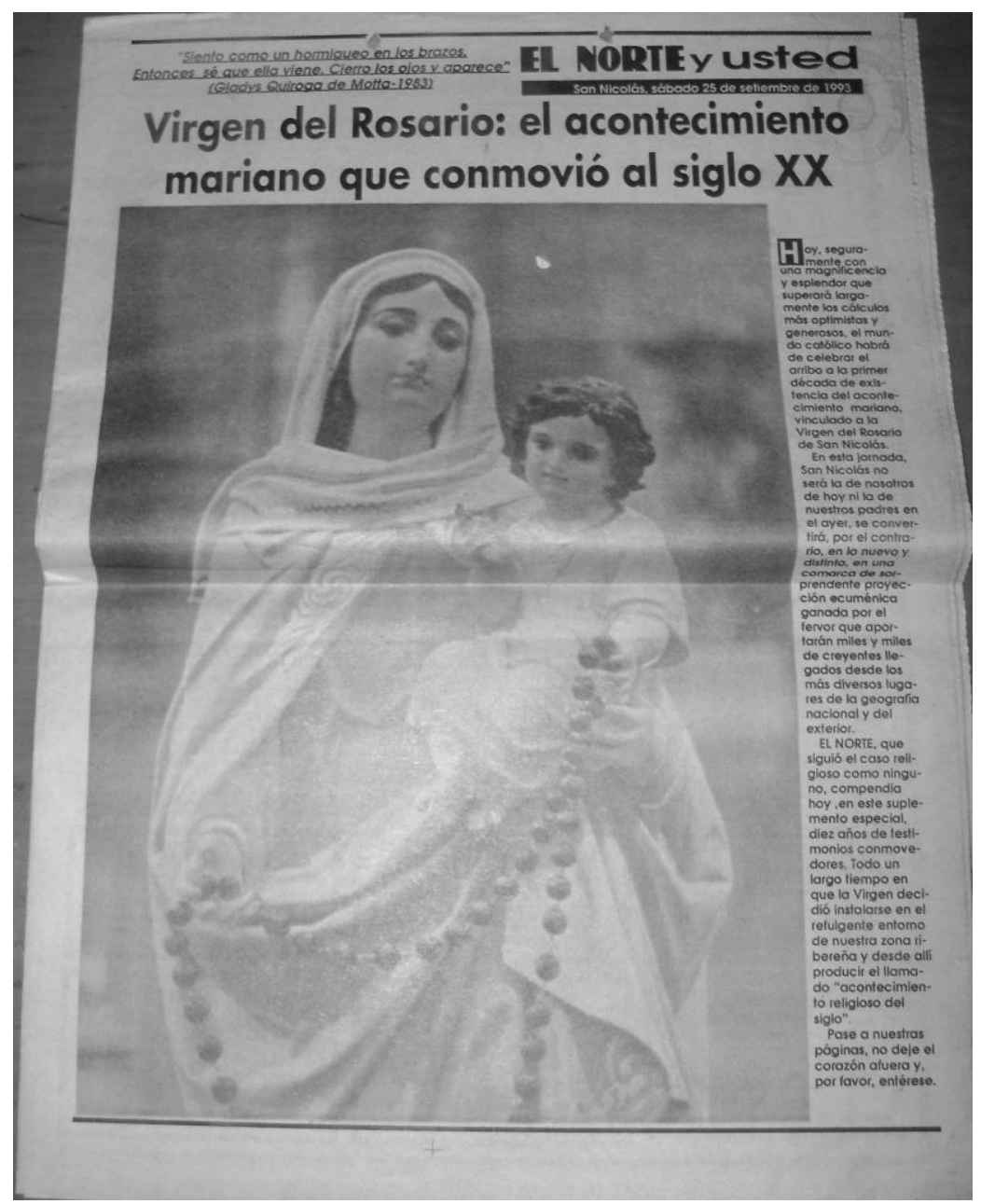

Fuente: El Norte (25 de septiembre de 1993).

Costilla, J. (2021). De milagros, imágenes y santuarios: apropiaciones simbólicas en tres cultos católicos sudamericanos. Revista Cultura y Religión, 15(2), 167-209. 
La elección de estos casos paradigmáticos obedeció a distintas cuestiones. En principio, los tres cultos comparten una serie de características: vigencia actual; magnitud y extensión de la devoción; vinculación con identidades sociopolíticas oficiales (a nivel municipal y/o nacional); y pertenencia a un área geohistórica común, dentro de Hispanoamérica y del espacio colonial del Virreinato peruano. También presentan marcadas diferencias que enriquecen la comparación: las imágenes implicadas (dos vírgenes y un Cristo), los contextos de surgimiento y las condiciones geopolíticas. Contrastan un pueblo de indios andino, una ciudad que fue sede arzobispal y capital virreinal -con población multiétnica y predominio de afrodescendientes-, y una localidad ubicada entre Buenos Aires y el litoral argentino -con población criolla e inmigración italiana desde fines del siglo XIX. Temporalmente, se oponen dos cultos de origen colonial frente a uno surgido en las últimas décadas, cuya inclusión se hizo en calidad de contracaso.

De ese modo, la referida investigación doctoral permitió demostrar cómo ciertos hechos observados en un santuario colonial se replican en un santuario contemporáneo. Y más allá de las diferencias contextuales, es posible reconocer regularidades a través del tiempo y del espacio. Una de ellas tiene que ver con los protagonistas de las trayectorias históricas de los santuarios. En todos los casos intervinieron actores semejantes y comprobamos su papel en la construcción de los cultos a través de acciones -hasta cierto puntoequivalentes. Encontramos, así, autoridades católicas en distintos niveles (desde curas párrocos hasta obispos -incluyendo como poder supremo al obispo de Roma), órdenes y congregaciones religiosas, asociaciones laicas, ${ }^{2}$ devotos no

\footnotetext{
${ }^{2}$ Respecto a las órdenes y congregaciones, hemos mencionado ya a las de San Agustín y San Francisco en Copacabana, como así también a las religiosas Nazarenas en Lima. Pero resta señalar a dos congregaciones que han estado vinculadas al santuario mariano de San Nicolás, aunque su injerencia en el culto haya sido menor: los Hijos del Sagrado e Inmaculado Corazón de María y las Hijas de María del Rosario de San Nicolás (Costilla, 2013). Entre las asociaciones laicas, además de la ya destacada Hermandad del Señor de los Milagros, se incluyen también una temprana cofradía de la Virgen de Copacabana y una asociación de fieles
}

Costilla, J. (2021). De milagros, imágenes y santuarios: apropiaciones simbólicas en tres cultos católicos sudamericanos. Revista Cultura y Religión, 15(2), 167-209. 
institucionalizados -ya sean feligreses locales o peregrinos-, autoridades y funcionarios del gobierno secular, agentes de prensa y representantes de cada una de las sociedades locales: comerciantes, artistas, académicos, etc.

Desde una lógica contemporánea occidental -secularizada- es posible clasificar a estos distintos actores de acuerdo a sus relaciones con el campo religioso, entendido este como una esfera de relaciones con un interés y un capital propio, distinguida -aunque no completamente separada- de otros campos de la dinámica social (Bourdieu, 2009; Fraga, 2016; Masferrer Kan, 2004). Así, no serían agentes propios de este campo los representantes del gobierno secular y de la sociedad que hoy definimos como "civil", aunque sus acciones no dejen de ser decisivas en materia religiosa. Pero en el contexto colonial estas separaciones estaban ausentes, en la medida en que toda la sociedad vivía bajo el denominado "régimen de cristiandad" -y porque tampoco se las reconocía en las cosmovisiones nativas americanas y africanas. Por lo tanto, debemos ser cautelosos en este punto al establecer comparaciones a largo plazo.

Tomando en cuenta la diversidad de actores, resultó relevante formular preguntas sobre usos y apropiaciones del símbolo religioso, para descubrir qué intereses estratégicos se movilizan en torno a estos fenómenos y evaluar hasta qué punto es posible definir motivaciones compartidas. Fueron claves, en esta tarea, los aportes teóricos de la antropología simbólica, articulados con aquellos de la sociología de la religión y con enfoques históricos y filosóficos sobre simbología sagrada. Sobre todo, se consideró que la antropología simbólica o interpretativa constituye una perspectiva de análisis con potencial para el

de la Virgen de San Nicolás. La primera, según fuentes de la época, quedó constituida desde el momento en que la imagen de la Virgen fue ingresada en Copacabana (1583) y continuó al menos hasta mediados del siglo XVII, como cofradía de indios pero integrada también por religiosos y autoridades coloniales locales (como el cura y el corregidor) (Ramos Gavilán, [1621]1976). La segunda es el denominado Movimiento Mariano de San Nicolás, constituido como órgano de difusión del culto a la Virgen del Rosario desde sus primeros años.

Costilla, J. (2021). De milagros, imágenes y santuarios: apropiaciones simbólicas en tres cultos católicos sudamericanos. Revista Cultura y Religión, 15(2), 167-209. 
estudio comparado, y válida para establecer hipótesis generales sobre los santuarios católicos, al menos en el contexto latinoamericano.

En primer lugar, podemos afirmar que los símbolos religiosos forman parte de un sistema solidario de símbolos que movilizan a las personas en relación a lo sagrado (Costilla, 2014; Durkheim, [1912] 1968; Geertz, 1987; Hervieu Léger, 2005; Wright, 2015) y que se integran en un particular universo de tiempos, lugares, ritos, creencias, narrativas, objetos, costumbres, etc. que los fieles experimentan y recrean más allá de las doctrinas eclesiásticas (Masferrer Kan, 2004; Paden cit. en Wright, 1998). A su vez, tomado como entidad opaca y polisémica, el símbolo religioso es siempre actualizado e interpretado desde luchas hermenéuticas ancladas históricamente en luchas sociales y políticas (cfr. Carvalho, 2000; Dri, 2012; Eliade, 1994; Geertz, 1987; Ricoeur, 1976; Turner, 1980).

Ahora bien, ¿cómo accedemos a esos significados y luchas de sentido que subyacen a un símbolo religioso? En esta investigación seguimos la estrategia metodológica propuesta por el antropólogo V. Turner (1980, 1969), quien señaló tres vías de acuerdo a tres campos de significación: una exegética, basada en las interpretaciones nativas (endógenas); una observacional, que induce significados desde el empleo de un símbolo; y una interpretativa, correspondiente a cómo reconstruimos, desde un estudio previo de la sociedad en cuestión, las relaciones que los símbolos mantienen entre sí. Estas tres vías, a su vez, son compatibles con la perspectiva filosófica hermenéutica que propone articular la revelación y la sospecha (Ricoeur, 1983; Wright, 2015); esto es, combinar la "escucha" atenta sobre aquello que el símbolo nos revela, en las explicaciones nativas, con la voluntad de examinar esos sentidos "por detrás" del símbolo, desentrañando el proceso que lo constituyó como tal. En las variadas fuentes de este trabajo, las interpretaciones y comportamientos fueron recuperados de maneras directas e indirectas, contrastando y triangulando

Costilla, J. (2021). De milagros, imágenes y santuarios: apropiaciones simbólicas en tres cultos católicos sudamericanos. Revista Cultura y Religión, 15(2), 167-209. 
registros entre documentación escrita, testimonios orales y la acción simbólica directamente observable.

$\mathrm{Al}$ aplicar este marco teórico-metodológico al estudio de los santuarios, se han podido establecer tres afirmaciones sobre sus simbologías. La primera es que el milagro cristiano -acontecimiento culturalmente interpretado como tal (Sahlins cit. en Costilla, 2014)- puede ser entendido como símbolo religioso; es decir, que junto a la definición teológica del milagro en tanto signo de dios y a la percepción devocional (o popular) como hecho que supera las expectativas de los fieles (Calavia Saez, 2002; Jacobo Albarrán, 2014; Marzal, Lorandi y Schaposchnik cit. en Costilla, 2010), sumamos una tercera definición hermenéutica. Ésta deriva de nuestra perspectiva como analistas sociales, desde la cual observamos cómo el milagro resulta interpretado y manipulado desde distintos actores. Pero además el milagro puede corresponder a una imagen, ya que en el mundo católico los sucesos prodigiosos suelen estar ligados a quienes los realizan: representaciones materiales de seres sagrados como Jesucristo, los santos y la Virgen María en sus variadas advocaciones. De hecho, aquellos suelen volverse el fundamento de la veneración que se les rinde a estas figuras. $\mathrm{Y}$ en el culto a imágenes milagrosas es clave también el propio lugar donde la mismas permanecen: los santuarios, entendidos como poderosos sitios sagrados (Acosta Luna, 2011; Eliade, 1954; Schwarz, 2008; Steil, 2002), irradiadores y congregadores, y a la vez como relevantes centros de peregrinación -y celebración- para las ciudades y localidades donde se ubican (cfr. Ameigeiras y Suárez, 2011; Carballo, 2009-2010; Díez Taboada, 1989; Ferro Medina, 2010).

Puede verse entonces que los santuarios católicos, con sus imágenes y los milagros a ellas atribuidos, son expresiones de una misma potencia sagrada, aquella que se corporiza en la imagen, pero que se extiende hacia su templo y sus manifestaciones (cfr. Fogelman, 2013). A su vez, podemos afirmar que los tres actúan como símbolos por su carácter polisémico y por ser focos de múltiples apropiaciones. Ante tales observaciones, contrastadas en la tesis, se

Costilla, J. (2021). De milagros, imágenes y santuarios: apropiaciones simbólicas en tres cultos católicos sudamericanos. Revista Cultura y Religión, 15(2), 167-209. 
ha establecido que la simbología central (o dominante) en cada uno de los cultos católicos analizados corresponde a un complejo de tres dimensiones inseparables: imagen, milagro y santuario. En otras palabras, podemos plantear que no se trata de tres símbolos distintos, sino de un solo símbolo sagrado de carácter tripartito o tridimensional.

Vinculada a este planteo, una tercera afirmación se refiere al proceso de conformación de la simbología sagrada de cada culto. Pudo demostrarse que la trayectoria histórica de cada santuario mostró un camino distinto en cuanto al orden en que se configuraron los tres aspectos del símbolo central. En Copacabana fue fundante el santuario por tratarse de un centro sagrado prehispánico; luego siguió la imagen tallada por un nativo; y finalmente el milagro, aquel que consagró a la Virgen como objeto de culto digno para cristianizar ese espacio pagano. En Lima, en cambio, el símbolo fue primero la imagen: el Cristo pintado en una cofradía de angoleños; después fue el milagro de conservación frente a los sismos; y por último el santuario, erigido una vez que la imagen fue aceptada. En el reciente caso de San Nicolás fue disparador el milagro: el fenómeno de apariciones marianas; luego aquel se materializó en una imagen, guardada en la catedral; y al final se edificó el santuario. Estas diferencias en la dimensión fundante del símbolo tripartito, se corresponden además con un particular anclaje del culto sobre ese aspecto; es decir, que en cada caso se registró una gravitación simbólica específica, reiterada en diversas situaciones: en Copacabana tiene un mayor peso el santuario, en Lima se destaca la imagen del Cristo y en San Nicolás es resaltado el milagro o "acontecimiento mariano" (ver Figura $\mathrm{N}^{\circ} 3$ ).

Con todos estos planteos y premisas expuestos, pasamos a desarrollar los usos y apropiaciones de estos símbolos religiosos en sus tres aspectos y en relación con distintos momentos históricos.

Costilla, J. (2021). De milagros, imágenes y santuarios: apropiaciones simbólicas en tres cultos católicos sudamericanos. Revista Cultura y Religión, 15(2), 167-209. 


\section{Polisemias en acción: usos y apropiaciones simbólicas en perspectiva comparada}

El relevamiento comparativo y de larga duración sobre los significados que han condensado las tres simbologías religiosas, permitió registrar que estas han compartido -y comparten- buena parte de sus polisemias. En líneas generales, los significados corresponden a tres perspectivas nativas: una eclesiástica-teológica, una devocional y otra que podríamos definir como secular o social, articulada en algunos casos con las dos primeras. Vinculados a estas significaciones, entonces, pueden observarse distintos usos y apropiaciones que los actores de cada culto han expresado respecto a sus símbolos, en sus tres aspectos (imagen, milagro, santuario) -entendiendo por apropiación, el empleo y la interpretación de tales símbolos (cfr. Carvalho, 2000; Dri, 2012; Fogelman, 2014). Para analizar la variedad de ejemplos relevados, se estableció una clasificación operativa de acuerdo con cinco modalidades de usos/apropiaciones del símbolo religioso: (1) evangelizadores /civilizadores, (2) devocionales, (3) político-eclesiásticos, 4) sociopolíticos (incluyendo apropiaciones socioétnicas) y (5) económicos. Aunque la división es netamente analítica, con límites difusos, cada categoría presenta ejemplos singulares, en términos de una particular relación entre el símbolo religioso e intereses sociales que exceden lo estrictamente devocional o pastoral -lo cual, en un contexto contemporáneo, puede expresar relaciones entre el campo religioso y otros campos sociales (político, socioétnico, económico, etc.). ${ }^{3}$

\footnotetext{
${ }^{3} \mathrm{Si}$ bien se busca ofrecer un panorama lo más amplio posible, por razones de espacio he seleccionado solo algunos ejemplos en cada categoría y los expuse de manera abreviada; motivo por el cual tampoco he incluido en todas las situaciones ejemplos relativos a los tres casos. Podrían, además, reconocerse otros usos posibles que no consideré en mi trabajo: por ejemplo, un uso estético o un uso artístico, entre otros.
}

Costilla, J. (2021). De milagros, imágenes y santuarios: apropiaciones simbólicas en tres cultos católicos sudamericanos. Revista Cultura y Religión, 15(2), 167-209. 


\section{Usos evangelizadores /civilizadores}

Este tipo de apropiación se ha observado de parte de agentes eclesiásticos y estatales, con dos objetivos principales: conversión y control social. Para los casos de Copacabana y Lima, se registran especialmente en las fuentes del período colonial, como parte del proyecto de incorporación de las poblaciones indígenas y afrodescendientes a las pautas cristianas-occidentales. Recordemos que durante el llamado "régimen de cristiandad" colonial las funciones de gobierno en materia espiritual y temporal se superponían permanentemente, ya que Iglesia y Estado no constituían agentes separados (Di Stéfano y Zanatta, 2000; Estruch, 2017). Por ese motivo, las apropiaciones evangelizadoras/civilizadoras de las imágenes de la Virgen de Copacabana y del Señor de los Milagros se enmarcaron en ese gran interés común que involucró a los poderes coloniales, en que la conversión religiosa fue solo un engranaje más dentro del sistema de expansión imperial política y económica.

Ambas imágenes coloniales comparten además el hecho de haber sido inicialmente rechazadas por las autoridades, debido a sus raíces paganas. Es decir, que su apropiación con fines de conversión/control implicó una cierta depuración de las mismas. Con el Señor de los Milagros se registró un ejemplo en 1766, cuando fueron empleados tanto el Cristo como uno de sus milagros más emblemáticos: su conservación tras un fuerte sismo en 1655. En una publicación que se proponía contar la "verdadera historia" de la imagen como forma de "propagar su mayor veneración y culto", dicho terremoto fue resignificado y planteado como consecuencia de las "bárbaras costumbres" de los negros cofrades:

instado N. Sr. de las torpezas y graves desacatos que cometían los negros delante de su imagen, e bailes y otros entretenimientos de sus bárbaras costumbres, arruinó enteramente con aquel temblor las casas, los corrales y

Costilla, J. (2021). De milagros, imágenes y santuarios: apropiaciones simbólicas en tres cultos católicos sudamericanos. Revista Cultura y Religión, 15(2), 167-209. 
todas las paredes de la cofradía, dejando solamente indemne el trozo de la que contenía a la divina imagen (Vásquez de Novoa, [1766]1868, p. 4).

El autor del escrito era abogado de la Real Audiencia y producía su obra en un año en que se recolectaban fondos para renovar el edificio del santuario. Podemos interpretar entonces que esta autoridad real se apropió del famoso milagro-símbolo en un sentido civilizador: al relatar una condena del Cristo hacia los homenajes que los negros le rendían, exponía una crítica al sector socioétnico más vinculado al santuario.

Otro ejemplo ilustrativo lo podemos observar en el culto de Copacabana contemporáneo. En el año 2007, posterior a la asunción del presidente Evo Morales, la Iglesia católica boliviana, ${ }^{4}$ junto a intelectuales y sectores cercanos del poder político, inició un proceso para beatificar al escultor de la Virgen: el descendiente incaico Francisco Tito Yupanqui. Esto implicó por un lado una sacralización de su figura, lo cual se refleja en una publicación -de edición trilingüe: español-aymara-quechua- que identifica su historia de producción de la imagen con el calvario de Jesucristo (Arduz Ruiz, 2007a). Pero, al mismo tiempo, la postulación permitió reforzar el papel evangelizador de ambos Yupanqui y Virgen- y reprodujo discursos característicos del período colonial, que demonizan lo nativo. Esto último se advierte, por ejemplo, en la escena de una de las estaciones del "calvario del escultor", donde la Virgen intercedía por él frente al intento del "maligno" de robarle una planta sagrada nativa. Allí se representa al demonio asociado a símbolos incaicos -brazaletes dorados y un tocado con plumas, similar a la mascaypacha que lleva Yupanqui (ver Figura $\left.\mathrm{N}^{\circ} 4\right)$.

\footnotetext{
${ }^{4}$ Nos referimos específicamente a los franciscanos administradores del santuario y a devotos de las ciudades de Potosí y La Paz (ligadas a la historia de creación de la imagen por el derrotero de su escultor). Sus acciones, además, se enmarcan en el contexto político del cambio de gobierno de ese año (2007): desde el ascenso del Movimiento al Socialismo (MAS), en el año 2006, se había iniciado un período de mayores enfrentamientos entre Estado nacional e Iglesia católica boliviana, lo cual repercutió en el Santuario de Copacabana, sobre todo con una disminución del interés estatal sobre el mismo (Costilla, 2014).
}

Costilla, J. (2021). De milagros, imágenes y santuarios: apropiaciones simbólicas en tres cultos católicos sudamericanos. Revista Cultura y Religión, 15(2), 167-209. 
Figura $\mathbf{N}^{\circ}$ 4: Dibujo de Yupanqui en Potosí,

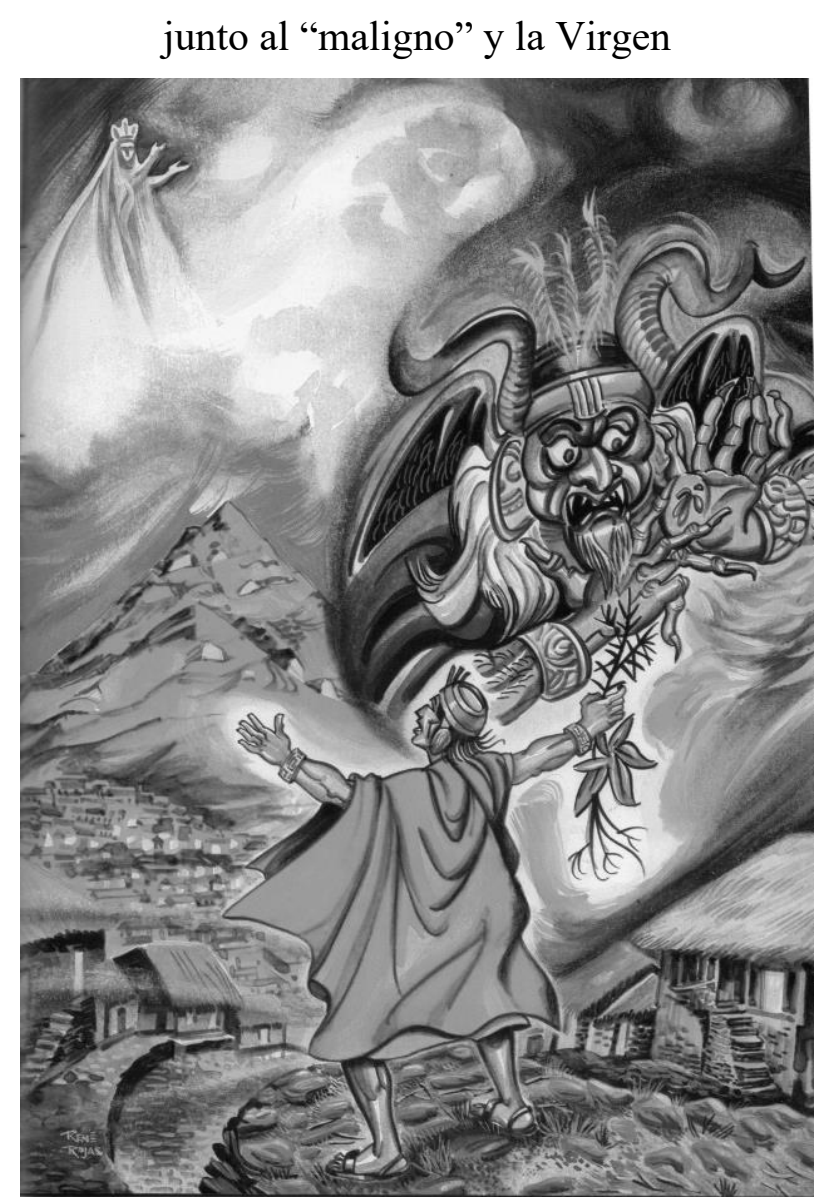

Fuente: René Rojas N. cit. en Arduz (2007a, p. 47).

En este sentido, no es extraña la siguiente expresión que publicaba un diario local en ese mismo año 2007:

Quiera el Señor conceder a Bolivia la gracia de la beatificación del Siervo de Dios Tito Yupanqui, precisamente ahora para hacer frente a los desafíos críticos que atraviesa nuestra patria. [...]se está produciendo un rebrote indiscriminado de mitos y ritos autóctonos, algunos de los cuales como los sacrificios (willanchas) al sol, a la pachamama o a otros entes telúricos atentan contra la fe en Jesucristo, Nuestro Señor. (Manzanera, 3 de agosto de 2007, s. p.)

Costilla, J. (2021). De milagros, imágenes y santuarios: apropiaciones simbólicas en tres cultos católicos sudamericanos. Revista Cultura y Religión, 15(2), 167-209. 


\section{Revista Cultura y Religión Vol. XV, 2021 № 2 (julio-diciembre)}

Según queda expuesto, la imagen de Copacabana resultó indirectamente apropiada para proponer una (re)conversión de la población andina. La Virgen, en tanto agente milagroso, extendía su potencia sagrada sobre la figura de quien la talló en 1583, quedando ambos como capital simbólico clave dentro del campo religioso boliviano, especialmente Yupanqui por su potencialidad para la identificación indígena con el catolicismo. En un contexto político donde la cosmovisión andina estaba siendo reivindicada, debido al perfil cultural de varios funcionarios estatales, dicha apropiación puede entenderse además como un embate eclesiástico frente el gobierno.

En su escenario de surgimiento contemporáneo, el culto a la Virgen de San Nicolás ha mostrado un fuerte encauzamiento eclesiástico, tanto desde la Iglesia local (sacerdotes, religiosos y laicos) como desde la curia romana. Esto se expresó en una constante intervención sobre el desarrollo del santuario, como así también en la producción de narrativas oficiales sobre la historia del símbolo. Así, el caso permite postular un uso evangelizador del símbolo religioso en términos de la "invención" de una devoción, independientemente de cómo ese símbolo haya sido apropiado por los devotos. Aunque lo mismo pueda plantearse para los casos de Copacabana y Lima, hemos visto que en ellos fue más sólida la base nativa -pagana- sobre la cual la Iglesia debió trabajar (cfr. Costilla, 2014).

\section{Usos devocionales}

Desde el punto de vista de los fieles, sus testimonios -históricos y actuales- permiten reconocer que los símbolos católicos, especialmente las imágenes y sus milagros, han sido apropiados colectivamente en relación con dos sentidos principales: la continuidad de antiguas sacralidades y la protección frente a catástrofes y crisis, ya sean de origen natural o social.

Costilla, J. (2021). De milagros, imágenes y santuarios: apropiaciones simbólicas en tres cultos católicos sudamericanos. Revista Cultura y Religión, 15(2), 167-209. 
La primera apropiación implica evocar seres tradicionales y actualizar prácticas y creencias de raigambre étnica (ofrendas, bailes, etc.) (Costilla, 2014). En cuanto al Señor de los Milagros, los registros coloniales sobre el comportamiento de los negros evidenciaron una apropiación de acuerdo con ritos de origen africano. Asimismo, las cualidades milagrosas del Cristo en relación con los temblores sugieren asociaciones con un dios nativo costeño, Pachacamac, también protector frente a los sismos (Rostworowski cit. en Costilla, 2010). Pero el caso en donde más se observa este tipo de continuidades es el de Copacabana: el único culto en donde el santuario -en tanto aspecto espacial del símbolo- habilitó el sostenimiento de sacralidades nativas. Entre estas se destaca la waka preincaica Copacabana, de la cual la Virgen heredó no solo el nombre, ${ }^{5}$ sino también su carácter acuático: declarada "Virgen y Señora de las Aguas" en 1630 y llamada "Mamita del Lago" (Elías 1981, p. 168; Valda, 1999, p.123). También se registran numerosas expresiones de religiosidad andina vinculadas al santuario de Copacabana: cultos solares de raíz incaica; cultos a cerros, rocas y piedras (ligados a la tradición minera y presentes en otros santuarios marianos de la región); y la veneración a la Pachamama (Arduz Ruiz, 2007a, 2007b; Arzans de Orsúa y Vela, [1705-1736] 1965; Entrevistado A, 20106; Entrevistada B ${ }^{7}$, 2010; Entrevistado $C^{8}, 2010$; Santuario de Copacabana, 2009; Valda, 1992).

El segundo uso señalado -protección frente a catástrofes/crisis-, corresponde a una situación frecuente en el universo cristiano (cfr. Christian, ([1981] 1991), expresada en los casos de Copacabana y Lima en invocaciones a

\footnotetext{
${ }^{5}$ Este, según las fuentes, significaba mirador del azul o de la piedra preciosa (Ramos Gavilán, [1621] 1976). No es un hecho menor que en la denominación de la Virgen se haya conservado la antigua expresión Copacabana y que esta haya opacado a la advocación hispana original (la Candelaria). Para los antiguos habitantes locales (los yunguyos), cuyas deidades habían sido relegadas por el culto solar de la religión oficial incaica, la Virgen de Copacabana reavivaba las connotaciones de una antigua waka.

${ }^{6}$ Entrevista realizada por la autora a feriante local, 4 de agosto de 2010, Copacabana.

${ }^{7}$ Entrevista realizada por la autora a devota peruana, 6 de agosto de 2010, Copacabana.

${ }^{8}$ Entrevista realizada por la autora a sacerdote del Santuario, 7 de agosto de 2010, Copacabana.
}

Costilla, J. (2021). De milagros, imágenes y santuarios: apropiaciones simbólicas en tres cultos católicos sudamericanos. Revista Cultura y Religión, 15(2), 167-209. 
las imágenes para afrontar fenómenos naturales característicos de cada región: sequías en el Altiplano (De la Calancha, [1657] 1972; Ramos Gavilán, [1621]1976) y terremotos en la costa peruana. En San Nicolás, en cambio, se expresaron apropiaciones simbólicas semejantes, pero frente a una devastadora crisis socioeconómica en la década de 1990, derivada de la privatización de una empresa siderúrgica vital para la ciudad (Sociedad Mixta Siderúrgica Argentina -SOMISA-, cfr. Rivero, 2008). En un escenario de crisis laboral, desamparo estatal y desarticulación social, la Virgen resultó esgrimida como símbolo de esperanza y protección (Bellande, 2001; Entrevistado D9 , 2005). Aunque tal apropiación pudo ser un factor decisivo en el vertiginoso desarrollo del culto, no alcanzó a imprimirle al símbolo un carácter devocional específico como en los otros santuarios.

\section{Usos político-eclesiásticos}

Esta categoría corresponde a agentes de la Iglesia católica, como unidad de sacerdotes y fieles -o especialistas y creyentes (Masferrer Kahn, 2004)-, desde intereses políticos que exceden lo religioso en su sentido más devocional o pastoral (en ocasiones, articulados con intereses estatales). Dentro de ella, los ejemplos relevados permitieron distinguir a su vez tres tipos de situaciones: (a) de consagración y/o uso fundacional del símbolo; (b) de reivindicación, para obtener reconocimiento y/o privilegios; y (c) de emblematización para exhibir una pertenencia católica.

\section{Consagración y/o uso fundacional}

El ejemplo más paradigmático en este punto es el santuario de Copacabana, cuya instalación, por parte de la Iglesia colonial, posibilitó

\footnotetext{
${ }^{9}$ Entrevistas realizadas por Cynthia Rivero a devoto local, miembro de la Comisión ProTemplo, 22 de septiembre y 4 de diciembre de 2005, San Nicolás. [gentileza de la entrevistadora].
}

Costilla, J. (2021). De milagros, imágenes y santuarios: apropiaciones simbólicas en tres cultos católicos sudamericanos. Revista Cultura y Religión, 15(2), 167-209. 
cristianizar un centro sagrado prehispánico y los itinerarios de sus peregrinaciones tradicionales (cfr. Costilla, 2010; Salles-Reese, 1997). Siglos después, el santuario y la imagen fueron el epicentro simbólico de un acto que integraba a la Iglesia y el Estado bolivianos: el 5 de agosto de 1925, la Virgen de Copacabana fue coronada por la Iglesia y declarada Madre y Reina de Bolivia, en una ceremonia que coincidió con el centenario de la independencia nacional. Las acciones implicaron, al mismo tiempo, una santificación de la simbología política y una consagración de la imagen y su santuario: la Virgen fue convertida en el símbolo religioso coronado por el Estado y esto contribuyó a la legitimación política de la Iglesia católica, en particular de la diócesis a cargo de culto (el Obispado de La Paz).

Sobre el culto al Señor de los Milagros destaco dos ejemplos de consagraciones oficiales coloniales, que expresan las articulaciones entre intereses religiosos y políticos propias del período. El primero refiere al año 1715, cuando el Cabildo de Lima declaró al Cristo como patrono de la ciudad y donó unos terrenos al beaterio nazareno que administraba el culto: en ese momento, llevaron la imagen procesional hasta el lugar para realizar una toma de posesión simbólica (Banchero Castellano, 1976; Sánchez Rodríguez, 2002). El segundo ejemplo corresponde a la inauguración del renovado templosantuario nazareno en 1771. Quien escribió la relación oficial del evento, un exfuncionario real, expresó que el Cristo de los Milagros simbolizaba la santificación del sitio: "Bien claro se ve, que eligió Dios y santificó este lugar" (Colmenares, 1771, p. XXXI). El autor, además, descendía de la "patrona" del monasterio y el templo -su principal benefactora-, lo cual demuestra que el símbolo religioso había sido eficazmente apropiado por esa familia de la elite limeña en consonancia con intereses eclesiásticos.

Otro ejemplo lo hallamos en San Nicolás. Considerando el año de surgimiento del culto (1983) -el del retorno democrático en Argentina, tras siete años de dictadura- y los indicios, en discursos y prácticas eclesiásticas, de

Costilla, J. (2021). De milagros, imágenes y santuarios: apropiaciones simbólicas en tres cultos católicos sudamericanos. Revista Cultura y Religión, 15(2), 167-209. 
una voluntad de "refundar" la diócesis (Pérez, 2007, p. 26), se observó un uso del símbolo-milagro para reivindicar una Iglesia afectada (con sacerdotes perseguidos y desaparecidos). Esto se plasmó, además, en el sitio elegido para fundar el culto mariano: unos terrenos donde, diez años atrás, se extendía un barrio de emergencia relocalizado durante la dictadura (Costilla, 2013; Rivero, 2008). Según las interpretaciones nativas, el lugar fue señalado por la Virgen en sus milagros y mensajes (Centro de Difusión del Movimiento Mariano San Nicolás, 1995); y tras una donación del municipio al obispado, fue convertido en el "campito de la Virgen". Con tales datos, es posible analizar que tanto el santuario como el milagro fueron inestimables recursos para santificar y resignificar un espacio cuya historia enfrentaba a sectores de la sociedad local.

\section{Reivindicación, privilegios y reconocimiento}

Aquí distinguimos a aquellas apropiaciones vinculadas a obtener reconocimientos político-eclesiásticos más puntuales: sacerdotes, órdenes religiosas y asociaciones laicas han recurrido a los símbolos católicos para reivindicar posiciones y privilegios frente a sus pares y ante las autoridades eclesiásticas o civiles. En el caso de Copacabana, esto quedó demostrado en las crónicas agustinas del siglo XVII (De la Calancha, [1639] 1972; Ramos Gavilán, [1621]1976) o en los discursos de franciscanos durante los siglos XIX y XX, cuando recurrieron tanto al santuario como a la imagen y a sus milagros iniciales para enaltecer su lugar como antiguos guardianes de la Virgen. Entre los milagros se destaca uno muy temprano (1582), sucedido en el convento franciscano de La Paz cuando Yupanqui perfeccionaba allí a su recién tallada imagen: la Virgen desprendió rayos de luz frente al fraile que la tenía en su celda. Al quedar el suceso registrado como la primera manifestación milagrosa de la imagen, los franciscanos permanecieron como protagonistas del origen del culto. Cuatro siglos después, cuando llevaban casi cien años como administradores del santuario, reivindicaban su posición con estas palabras:

Costilla, J. (2021). De milagros, imágenes y santuarios: apropiaciones simbólicas en tres cultos católicos sudamericanos. Revista Cultura y Religión, 15(2), 167-209. 
En la restauración de Copacabana como centro de vida cristiana acendrada ha tenido y tiene mucho que ver la Orden franciscana [...] quienes a través de 81 años de atención continua y sacrificada al culto de la Mamita y bien espiritual de sus feligreses y peregrinos, han logrado colocar a Copacabana como faro luminoso del espíritu [...] el santuario de La Virgen que se levantó a orillas del Titicaca surgió de las ruinas en que se encontraba a mediados del siglo XIV (sic) y, merced a los Franciscanos, ha logrado la vitalidad y auge presente. (Elías, 1981, p. 169)

Puede verse cómo este fraile, para glorificar la labor franciscana “continua y sacrificada al culto de la Mamita”, recurría sobre todo al símbolosantuario.

Sobre el culto limeño observamos que la imagen fue apropiada por las dos instituciones que custodiaron al santuario desde su surgimiento: la Hermandad (de cargadores, sahumadoras y cantoras) y el Monasterio de Nazarenas. El Señor de los Milagros fue el pilar simbólico que consolidó y sostuvo a ambas congregaciones, al tiempo que estas han sido las principales promotoras del culto -rol que define sus autorreconocimientos. Aunque la apropiación resulta evidente en ambos casos, podemos agregar que el Monasterio guarda, bajo un restringido acceso, los manuscritos más tempranos sobre el culto y ha editado obras sobre su historia. Respecto a la Hermandad, además de presentarse como los primeros devotos de la imagen, han instalado su culto alrededor del mundo, en las más de cien ciudades que concentran migrantes peruanos.

En relación con San Nicolás existen dos congregaciones religiosas -las Hijas de María del Rosario y los Hijos del Sagrado e Inmaculado Corazón de María- que mostraron apropiaciones semejantes, aunque con un perfil más bajo dentro del culto (Costilla, 2014). Pero el ejemplo más singular se detecta en el origen de la imagen nicoleña, un siglo antes del denominado "acontecimiento

Costilla, J. (2021). De milagros, imágenes y santuarios: apropiaciones simbólicas en tres cultos católicos sudamericanos. Revista Cultura y Religión, 15(2), 167-209. 
mariano"; si bien aún no se había configurado el símbolo religioso que este trabajo analiza, se trataba de la misma virgen en la misma diócesis. Cuando en 1884 la imagen fue entronizada dentro de la catedral local -reinaugurada tras su destrucción por un polvorín estatal-, llegó como un símbolo católico clave para reivindicar a una Iglesia relegada frente a los embates del Estado liberal, a nivel local y nacional (Costilla, 2014; cfr. Fogelman, 2013). Asimismo, el origen italiano de la imagen permite inferir intereses ligados al contexto católico de romanización. Tal vez por esos motivos, la Virgen no llegó en ese entonces a consolidarse como símbolo religioso central, con los milagros y el santuario que cien años después la posicionaron como eje simbólico de la Iglesia nicoleña.

\section{Emblematización para exhibir pertenencia católica}

Esta variedad de usos político-eclesiásticos se manifestó en la exhibición de los símbolos católicos como signos distintivos/identitarios. Un ejemplo peculiar lo registramos en Lima, cuando se creó el actual himno al Señor de los Milagros, en 1955. Si analizamos el hecho a la luz del contexto eclesiástico -momento en que surgía un laicado militante que procuró inculcar sentidos de pertenencia y distinguir a los católicos practicantes (Klaiber, 1996), podemos interpretar que el Cristo fue apropiado como emblema de catolicismo. Años después, la imagen siguió siendo esgrimida como estandarte católico peruano frente a las tensiones con protestantes evangélicos (Cárdenas, 19 de octubre de 2008). En tal sentido, un signo clave para los peruanos es el hábito morado de las religiosas nazarenas, adoptado por la Hermandad (ver Figura $\mathrm{N}^{\circ} 5$ ) y usado por fieles de distintas edades durante los festejos anuales.

En el culto de San Nicolás, por su parte, hace unos años (2013) el santuario ofrecía en su sitio web remeras con la estampa de la Virgen del Rosario, entre otros "productos religiosos" disponibles para compra online. Lo más elocuente aquí es la presencia de este merchandising mariano en un canal eclesiástico oficial, siendo la imagen utilizada para proponer y exhibir una

Costilla, J. (2021). De milagros, imágenes y santuarios: apropiaciones simbólicas en tres cultos católicos sudamericanos. Revista Cultura y Religión, 15(2), 167-209. 
pertenencia simbólica determinada. Aunque también es evidente la relación con otros usos que veremos -económicos-comerciales-, interesa resaltar el carácter de emblema católico que han recibido estos símbolos en circunstancias específicas. Por esto mismo, las apropiaciones aquí analizadas pueden ser distinguidas de la práctica más habitual y generalizada de usar objetos con el diseño del símbolo (medallas, remeras, llaveros, etc.), ya sea en forma cotidiana como en contextos rituales.

\section{Usos sociopoliticos}

Si bien en la categoría previa incluimos ejemplos sobre autoridades y/o intereses civiles/seculares, es en este punto donde encontramos apropiaciones del símbolo religioso en términos estrictamente políticos, desde diferentes niveles del gobierno secular colonial o desde distintas instancias estatales republicanas. También se incluyen acciones particulares o de ciertos sectores sociales cuyas motivaciones excedían lo meramente devocional. Como marco general para interpretar todos estos ejemplos, será fundamental la transición entre colonia y república (Guerra Martiniére, Gómez Acuña, Di Stéfano y Zanatta cit. en Costilla, 2014). Las implicancias de estos usos en un régimen de cristiandad -en el que se entrelazaban completamente lo religioso, lo político y lo social/civil- son muy diferentes a las que podemos inducir dentro del contexto republicano secularizado, con la separación paulatina entre esferas sociales y las inestables relaciones entre Iglesia católica y Estados nacionales, que han oscilado entre las confrontaciones y la mutua legitimación.

Los usos sociopolíticos más tempranos se detectaron a partir de procesos de diferenciación social y socioétnica en Copacabana durante el contexto colonial. En este pueblo de indios, los nativos cristianizados pudieron recurrir estratégicamente a los milagros de la Virgen para mantener -o construir- posiciones y privilegios en diversas situaciones: en relación a

Costilla, J. (2021). De milagros, imágenes y santuarios: apropiaciones simbólicas en tres cultos católicos sudamericanos. Revista Cultura y Religión, 15(2), 167-209. 
divisiones intraétnicas tradicionales (como entre las mitades andinas anansayaurinsaya, ${ }^{10} \mathrm{o}$ entre originarios y mitimaes -colonos-incaicos), a preeminencias entre linajes incaicos, o respecto a las autoridades coloniales (cfr. BouysseCassagne, Del Río, Medinaceli cit. en Costilla, 2010). También en Lima, los indígenas y africanos devotos del Cristo de Pachacamilla tuvieron oportunidad de emplear la imagen, y sus milagros, como herramientas de reconocimiento dentro de la sociedad colonial (Costilla, 2011). Al mismo tiempo, diferentes versiones sobre el origen del culto evidenciaron que la imagen y sus milagros fueron arena de lucha (Vólòshinov cit. en Costilla, 2014) entre distintos actores de la elite local: vecinos propietarios, curas, religiosos, alcaldes, virreyes y arzobispos.

En el culto limeño destacamos además una apropiación política que manifiesta una relativa continuidad entre colonia y república. La declaración del Cristo como patrono jurado de Lima por parte del Cabildo, en 1715, fue recuperada más de dos siglos después, cuando en 1937 el Municipio de Lima colocó un escudo de la ciudad en las andas procesionales de la imagen (Costilla, 2011). Aunque ocurrieron en coyunturas históricas muy diferentes, cabe interpretar un sentido similar en estos homenajes del gobierno local. En cuanto a la sociedad civil, la imagen limeña es esgrimida e invocada durante todo el mes de octubre (el de su celebración anual), incluso desde anuncios publicitarios (ver Figura $\mathrm{N}^{\circ}$ 5), tanto en medios de comunicación como en carteles y marquesinas de comercios e instituciones ubicados en las calles de los recorridos procesionales.

\footnotetext{
${ }^{10}$ Los descendientes incaicos, y entre ellos el escultor de la imagen, pertenecían a la mitad anansaya, que mantenía una tradicional preeminencia sobre la mitad urinsaya (recordamos que con la expansión imperial incaica esa relación entre mitades ya había sido reformulada: los originarios de los pueblos, bajo el dominio incaico, perdieron su preeminencia simbólica para quedar relegados a la mitad inferior). Por ese motivo, puede afirmarse que el culto a la Virgen de Copacabana expresa continuidades con estructuras políticas andinas, como las relaciones de poder entre parcialidades (cfr. Salles-Reese, 1997); estas pudieron reproducirse en el período colonial -simbólicamente- gracias a la entronización de una virgen elegida por esa mitad superior.
}

Costilla, J. (2021). De milagros, imágenes y santuarios: apropiaciones simbólicas en tres cultos católicos sudamericanos. Revista Cultura y Religión, 15(2), 167-209. 
Figura $\mathbf{N}^{\circ}$ 5: Anuncio publicitario con tributo a la imagen

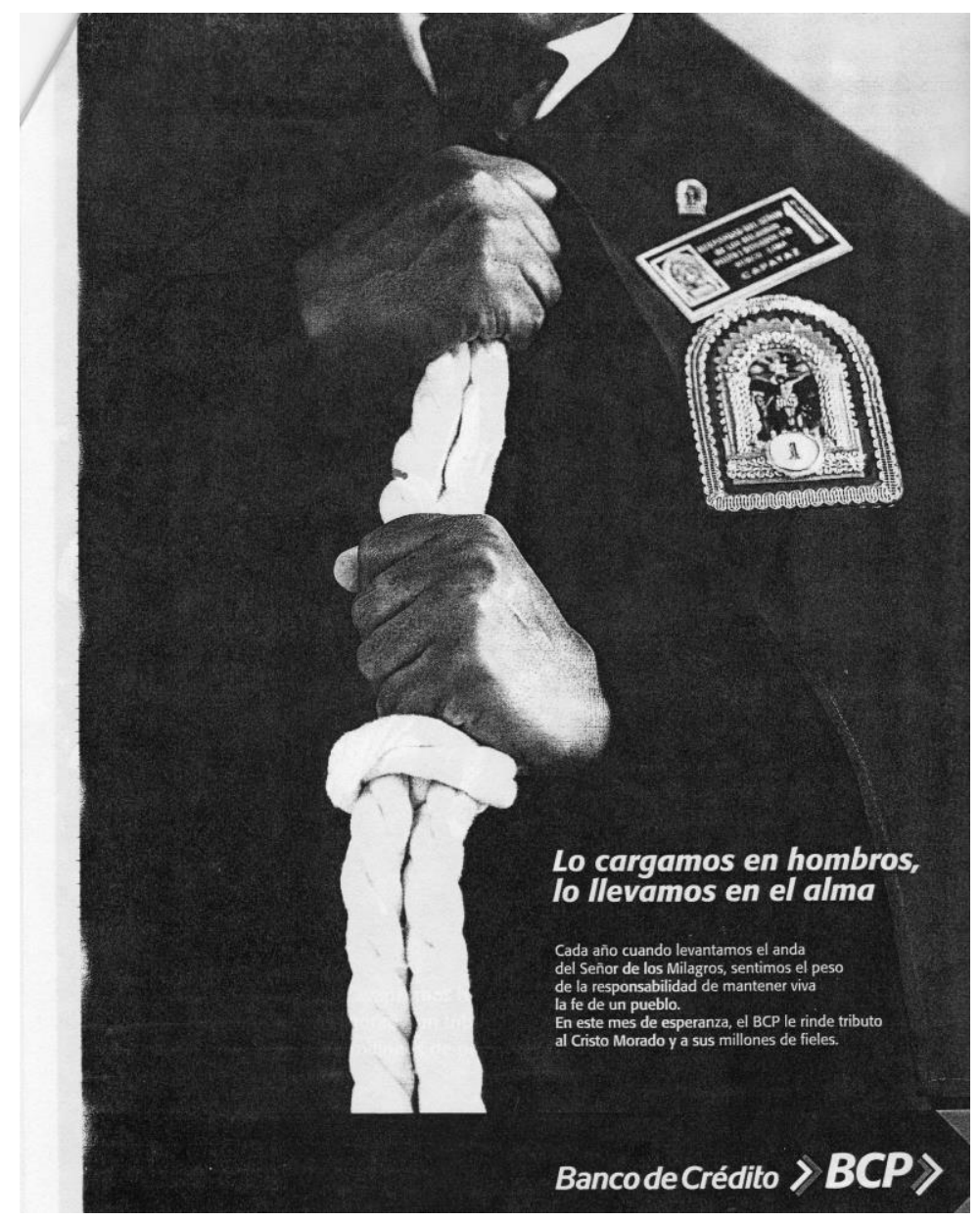

Fuente: Caretas (28 de octubre de 2004, p. 15).

En Bolivia, el contexto republicano ha dejado numerosas evidencias de apropiaciones políticas de la Virgen de Copacabana. La más significativa fue durante la ya comentada celebración del centenario boliviano en 1925, cuando el símbolo religioso consagró a la propia "nación boliviana", cuyo perfil procuraban delinear. Otro ejemplo destacable es el patronazgo de la Virgen sobre la Policía Nacional, luego de la Revolución boliviana de 1952 -cuando el poder armado fue estratégicamente transformado (Quintana Taborga cit. en Costilla, 2014). Tras una solicitud de las autoridades policiales al arzobispo tres cultos católicos sudamericanos. Revista Cultura y Religión, 15(2), 167-209. 
paceño, el 5 de diciembre de 1954 se proclamó a "la Mamita" como patrona y generala de la Policía Nacional y Carabineros (Elías, 1981; Santuario de Copacabana, 2007b). La ceremonia, en la cual la viuda de un general ofrendó una espada en las plantas de la imagen, expresó una articulación entre "fe religiosa" y "sentir revolucionario" nacionales (Dirección General de Carabineros y Policías de Bolivia, 1954). Podemos analizarla, además, como un acto oficial de legitimación mutua entre la fuerza armada policial y la imagen de Copacabana. Un carácter semejante, pero con matices propios, recibió la proclamación de la Virgen como patrona y almirante de la Fuerza Naval boliviana en 1969. El símbolo en este caso acompañaba el reclamo de una salida al mar para Bolivia, quedando reforzado su vínculo con el lago Titicaca (Santuario de Copacabana, 2007a): "cuando tuvo su trono a orillas de las azuladas aguas del Titicaca [...] la Virgen se constituyó en 'estrella del lago' y protectora de quienes lo surcan" (Elías, 1981, p.149).

Sobre San Nicolás pudo registrarse un uso oficial de la simbología mariana en el diseño que exhibía el banner principal del sitio web del municipio hasta el año 2011 (cuando renovaron la gestión): la Virgen en el centro, por detrás la catedral y a la derecha la cúpula del santuario. En general, como sucede en buena parte de los santuarios católicos contemporáneos, los tres casos revelaron estas apropiaciones en la presencia de autoridades estatales y funcionarios de gobierno durante las celebraciones anuales y ceremonias eventuales vinculadas a cada imagen religiosa. Sobre estas situaciones, sostenemos que la legitimación es siempre un proceso dialéctico, en el que resultan mutuamente consagrados tanto el símbolo como los agentes e instituciones que lo emplean. Se trata, además, de prácticas con un papel crucial en la producción de consenso y significados hegemónicos, especialmente para la construcción de comunidades imaginadas en distintos niveles, desde municipales hasta nacionales (Anderson y Ortemberg cit. en Costilla, 2014).

Costilla, J. (2021). De milagros, imágenes y santuarios: apropiaciones simbólicas en tres cultos católicos sudamericanos. Revista Cultura y Religión, 15(2), 167-209. 


\section{Revista Cultura y Religión Vol. XV, 2021 № 2 (julio-diciembre)}

Por último, en los dos cultos marianos estudiados (Copacabana y San Nicolás) se reconoció una patrimonialización de las imágenes y sus santuarios, a la cual podemos subrayar como apropiación política de lo religioso, característica del siglo XX. En Bolivia fue el símbolo-santuario el que mayor presencia tuvo como elemento patrimonializable. En el referido centenario patriótico de 1925, las autoridades políticas señalaron al santuario y a la imagen como parte del "tesoro público"; y a fines de los años sesenta, el primero volvió a ser presentado como "acervo Sagrado de la Nación" (Elías, 1981, p. 159; Estenssoro, 19 de mayo de 1925). El santuario nicoleño, por su parte, fue tempranamente proyectado como "exponente del acervo artístico de San Nicolás", cuando la Iglesia solicitó al intendente la donación de los terrenos para su construcción (Pérez, 1984 [documento transcripto en Pérez, 2007, p.305]). Así, el municipio y el obispado emplearon conjuntamente el símbolo religioso para forjar un patrimonio local.

\section{Usos económicos}

Esta última modalidad de apropiaciones, si bien ha sido la menos explorada, permitió abordar líneas de análisis que, en su mayoría, ya han sido abiertas en relación con la problemática de los santuarios católicos. Una de ellas fue la del turismo religioso, ligado a la patrimonialización analizada previamente. La resignificación turística del símbolo religioso se visibilizó sobre todo en las últimas décadas, mostrando intersecciones entre el campo político y el económico. La Virgen de Copacabana, por ejemplo, -junto a su santuario-basílica- ha sido estratégicamente construida como símbolo nacional en relación con el turismo que ingresa al país y con distintos reclamos a las autoridades por parte de fieles de La Paz (Asturizaga, 29 de noviembre de 2002; "Fundador de Cruzada...", 22 de agosto de 2010; "La Cruzada...", 15 de julio de 2009; Manzanera, 3 de agosto de 2007; entre otros). También la imagen de

Costilla, J. (2021). De milagros, imágenes y santuarios: apropiaciones simbólicas en tres cultos católicos sudamericanos. Revista Cultura y Religión, 15(2), 167-209. 
San Nicolás, en los años más críticos para la ciudad, fue encarrilada en un sentido turístico con una intervención coordinada de funcionarios municipales, sacerdotes diocesanos y entidades de la sociedad civil (Costilla, 2014; cfr. Flores, 2011).

Una segunda línea de análisis la encontramos en el uso comercial del símbolo, al cual registramos desde tiempos coloniales. En 1651, los sacerdotes de Copacabana denunciaban que el corregidor seguía este tipo de intereses lucrativos, por aprovechar la procesión de la Virgen para "hacer su negocio" gracias a la mayor afluencia de gente (De la Calancha, [1657] 1972, p. 622). En general, es sabido que los santuarios promueven este tipo de usos, ya que la concentración de devotos, sobre todo en celebraciones y procesiones especiales, resulta aprovechada para montar negocios. Esto involucra tanto a pequeños comerciantes y familias que se crean una momentánea fuente de ingresos, como a las acciones planificadas de autoridades políticas, sacerdotes y empresarios locales (Levaggi, 2007; Rivero, 2008). En cuanto a la comercialización de objetos con el símbolo religioso, observada en los tres santuarios en puestos y locales aledaños, se ha interpretado que esto convierte a la religión en un producto cultural vendible (Levaggi, 2007). Pero aun así, el uso masivo de esos objetos implica un consumo devocional que es ajeno al sentido económico, por lo cual las transacciones comerciales pueden evidenciar el arraigo de un culto (cfr. García Canclini, 2006; Steil, 2002).

Finalmente, otra cuestión tradicional en el aspecto económico de los santuarios católicos son las limosnas y ofrendas que reciben habitualmente. Un ejemplo singular se ha relevado en el caso de Copacabana, cuando el escultor Yupanqui recurrió a la Virgen para solicitarle una retribución económica personal al padre provincial de los agustinos: según quedó documentado en los primeros años del culto, aquel alegó su papel de creador de una imagen que "de tanto provecho" había sido para el "acrecentamiento de la fe" y la "extirpación de la Idolatría" (Ramos Gavilán, [1621] 1976, p. 204). Si bien no mencionaba

Costilla, J. (2021). De milagros, imágenes y santuarios: apropiaciones simbólicas en tres cultos católicos sudamericanos. Revista Cultura y Religión, 15(2), 167-209. 
explícitamente los ingresos del santuario, podemos deducir que en su pedido subyace cierta prerrogativa respecto a aquellos, dado su papel clave en el nacimiento del culto.

Pasando al nivel institucional, no son menores las implicancias económicas de documentar y proclamar milagros. Estas producciones escritas usualmente difundidas en torno a los santuarios (sobre todo en la órbita católica colonial, para contrarrestar los avances reformadores), además de fomentar la confianza de los fieles, han permitido captar nuevas ofrendas (Christian, ([1981] 1991) y contribuir al sostenimiento material de los templos. Esto se observa claramente en casos como el de San Nicolás, por la reciente construcción de su santuario y la decisión diocesana de hacerlo solo con la ayuda del "Pueblo de Dios" (Castagna, 26 de septiembre de 1986), lo cual hace necesarios permanentes llamados a la colaboración de los devotos.

\section{Conclusiones}

En el mundo católico, los milagros atribuidos a imágenes sacralizadas se vuelven focos de múltiples interpretaciones y podemos entenderlos como símbolos, es decir, como construcciones polisémicas. A su vez, estos milagros suelen conducir a prácticas de veneración en torno a santuarios, con lugares y tiempos consagrados. Tal proceso configura un símbolo complejo que caracterizamos como entidad triple: agente sacralizado (imagen), acciones milagrosas (hechos percibidos como milagros) y lugar de veneración (santuario). Son estos tres aspectos, según demostramos, los que conforman al símbolo religioso dominante en cada culto católico analizado. Se colige, entonces, que la simbología sagrada central de cada santuario fue configurada sobre esas tres entidades.

Respecto al proceso que dio lugar a estos símbolos católicos, se explicó cómo cada una de las simbologías emergió de una trayectoria particular, en la

Costilla, J. (2021). De milagros, imágenes y santuarios: apropiaciones simbólicas en tres cultos católicos sudamericanos. Revista Cultura y Religión, 15(2), 167-209. 
que podemos observar cuál de esos tres aspectos fue fundante o disparador para el surgimiento del culto. Con los casos aquí presentados partimos de tres situaciones distintas: el de Copacabana, asentado en un santuario lacustre y su sacralidad tradicional; el de Lima, centrado en una imagen-mural y el de San Nicolás, focalizado en un milagro de apariciones marianas. De este modo, la exploración histórica sobre cómo se conformaron estos símbolos -impulsada por la hermenéutica de la sospecha- permitió descubrir que cada culto expresa una gravitación simbólica particular, según cuál de las tres entidades fue fundante en él.

Estas interpretaciones, planteadas al inicio del trabajo, se fundamentan en los datos recogidos y en los marcos conceptuales referidos, pero podrán ser contrastadas $-\mathrm{y}$ eso se espera- a la luz de otras experiencias históricas y enriquecidas en la discusión teórica. Considero que extender esta propuesta de modelo analítico al estudio de otros santuarios latinoamericanos -incluso de otras regiones del orbe católico-, permitiría evaluar regularidades y/o singularidades en la forma en que los cultos se enlazan con las características socioculturales y político-eclesiásticas de los contextos donde se desarrollan y con las trayectorias históricas locales.

Por otra parte, más allá de la inclinación de cada culto hacia uno u otro aspecto del símbolo, los resultados del análisis comparativo, en la larga duración, sugirieron polisemias comunes a los tres casos y cinco modalidades distintas de apropiación simbólica: evangelizadora /civilizadora, devocional, político-eclesiástica, sociopolítica, económica. Es decir que, a pesar de las diferentes trayectorias que han tenido los cultos, en los tres reconocimos a actores sociales semejantes, y estos expresaron usos y apropiaciones del símbolo religioso en términos comparables. Podemos afirmar que sus acciones y discursos, de acuerdo con el contexto donde se enmarcaron, dieron cuenta de cómo las imágenes, sus milagros y los santuarios resultan empleados en relación con diversos fines e intereses.

Costilla, J. (2021). De milagros, imágenes y santuarios: apropiaciones simbólicas en tres cultos católicos sudamericanos. Revista Cultura y Religión, 15(2), 167-209. 


\section{Revista Cultura y Religión Vol. XV, 2021 № 2 (julio-diciembre)}

Respecto a las autoridades eclesiásticas y administradores de santuarios -sacerdotes, religiosos o laicos-, aunque se apropiaron de sus símbolos católicos, sobre todo en un sentido evangelizador/civilizador, expresaron otros usos posibles: en términos político-eclesiásticos, especialmente de manera consagratoria/fundacional, o con fines reivindicatorios, e incluso desde motivaciones económicas. Las apropiaciones político-eclesiásticas, en sus distintas situaciones, pueden interpretarse como estrategias de empoderamiento en tres niveles: de una congregación -religiosa o laica- frente a las demás; de una diócesis frente a otras o ante la propia sede romana; o de la Iglesia católica (como unidad de sacerdotes y fieles) frente a otras confesiones religiosas o frente al Estado secular.

Sobre los devotos fue particular el caso de los indígenas en Copacabana. En el contexto colonial, los milagros de la Virgen le permitieron a la población nativa legitimar su lugar dentro de la sociedad en tanto nuevos cristianos. Al mismo tiempo, tales milagros, y el posterior santuario, favorecieron la reconsagración de un lugar central de la geografía religiosa prehispánica, de manera que la sustitución cristianizadora también pudo incluir una estrategia nativa para reivindicar un espacio sagrado. Por otro lado, los fieles indígenas supieron recurrir al símbolo sagrado como herramienta para reproducir sus diferenciaciones y relaciones de poder tradicionales, así como para garantizar su acceso a ciertos espacios y beneficios. En el caso de Lima, detectamos usos similares de parte de los africanos, para quienes el Señor de los Milagros fue un símbolo clave, tanto en un sentido devocional como en términos socioétnicos y sociopolíticos. El hecho de registrar este tipo de apropiaciones étnicas, sobre todo en la etapa colonial, puede explicarse por la relevancia que los símbolos religiosos tenían dentro del régimen de cristiandad.

En el período republicano es destacable el ejemplo de la numerosa Hermandad del Señor de los Milagros, por la continuidad que sostuvo esta asociación de fieles limeños a partir de una incipiente cofradía en el siglo XVII.

Costilla, J. (2021). De milagros, imágenes y santuarios: apropiaciones simbólicas en tres cultos católicos sudamericanos. Revista Cultura y Religión, 15(2), 167-209. 
Como contracara, en el caso de San Nicolás no se registraron usos devocionales en términos arraigados en una cosmovisión local o en grupos sociales particulares, más allá de aquellos conformados específicamente para la difusión del culto (como el Movimiento Mariano). Consideramos que esto puede deberse no solo al carácter contemporáneo y reciente del culto, sino sobre todo a dos factores: uno, las características del surgimiento del símbolo, anclado en milagros de la Virgen María y sin conexión original con una imagen o un lugar concreto; otro, el perfil de los devotos, según el cual los peregrinos superan ampliamente a los feligreses locales.

En cuanto a las autoridades civiles, tanto coloniales como republicanas, se relevaron usos del símbolo especialmente en términos de legitimación y consagración. En el último siglo, además, coincidieron con la autoridad eclesiástica en apropiaciones desde dos sentidos: el patrimonial y el turístico, vinculados ambos a intereses que articulan el campo religioso con los campos político y económico. Y en esta dirección identificamos, asimismo, apropiaciones de parte de la sociedad civil: en los tres cultos ligadas a un uso más comercial del símbolo: en los casos de Copacabana y San Nicolás también conectadas con el uso turístico, y en Lima, un empleo del Cristo mucho más extendido entre distintas instituciones, empresas y actores particulares.

Con el análisis comparado de esta variedad de ejemplos, en clave histórica y antropológica, este trabajo espera aportar a la discusión sobre el lugar que los actores sociales le otorgan al símbolo católico, y cómo este ha operado en la dinámica social a lo largo de distintas etapas históricas. En un contexto actual, donde es posible establecer una relativa separación del campo religioso respecto de otros campos sociales, las apropiaciones simbólicas que este trabajo ha puesto en evidencia pueden contribuir al conocimiento sobre articulaciones históricas específicas entre la esfera de lo religioso y otros ámbitos de la interacción social. En definitiva, la perspectiva simbólica propuesta puede ser de utilidad para las investigaciones sobre este tipo de cultos

Costilla, J. (2021). De milagros, imágenes y santuarios: apropiaciones simbólicas en tres cultos católicos sudamericanos. Revista Cultura y Religión, 15(2), 167-209. 
religiosos, funcionando como un modelo para el estudio de santuarios católicos que podrá ser contrastado empíricamente en relación con otros contextos históricos, en particular dentro del ámbito latinoamericano.

\section{Referencias bibliográficas}

Acosta Luna, O. I. (2011). Milagrosas imágenes marianas en el Nuevo Reino de Granada. Madrid-Frankfurt: Iberoamericana-Vervuert.

Ameigeiras, A. y Suárez, A. L. (2011). La Virgen del Cerro en Salta. Continuidades y singularidades respecto a las principales apariciones modernas y contemporáneas. Cultura \& Religión, 5(2), 19-32.

Arduz Ruiz, M. (2007a). El calvario del escultor de Copacabana. La Paz: Campo Iris.

Arduz Ruiz, M. (2007b). Virgen de Copacabana, Reina del Cerro Rico de Potosí. La Voz del Santuario de Copacabana, 2(7), 9-12.

Arzans de Orsúa y Vela, B. (1965 [1705-1736]). Historia de la Villa Imperial de Potosí. Providence: Brown University Press.

Asturizaga Salmón, L. (29 de noviembre de 2002). "Copacabana requiere mayor atención". El Diario. Recuperado de http://www.eldiario.net/noticias/2002/2002_11/nt021129/1_02opn.html

Banchero Castellano, R. (1972). Lima y el mural de Pachacamilla. Lima: Jurídica.

Banchero Castellano, R. (1976). La verdadera historia del Señor de los Milagros. Lima: Inti-Sol Editores.

Bellande, E., Rodríguez S. (Productores), \& Bellande, E. (Director).(2001). Ciudad de María [Documental]. Argentina: La Burbuja Cine/Matanza Cine.

Bourdieu, P. (2009). La eficacia simbólica. Buenos Aires: Biblos.

Costilla, J. (2021). De milagros, imágenes y santuarios: apropiaciones simbólicas en tres cultos católicos sudamericanos. Revista Cultura y Religión, 15(2), 167-209. 
Bouysse-Cassagne, T. (1997). De Empédocles a Tunupa: evangelización, hagiografía y mitos. En T. Bouysse-Cassagne (ed.), Saberes y memorias en los Andes. In memorian Thierry Saignes (pp. 157-212). Lima: IHEAIFEA.

Braudel, F. (1953). El Mediterráneo y el mundo mediterráneo en la época de Felipe II. México: FCE.

Calavia Sáez, O. (2002). Las formas locales de la vida religiosa. Antropología e historia de los Santuarios de La Rioja. Madrid: Consejo Superior de Investigación Científica.

Carballo, C. (2009-2010). Peregrinos católicos y religiosidad popular en Argentina. Estudios Socioterritoriales. Revista de Geografía, (8), 53-69.

Cárdenas, M. Á. (19 de octubre de 2008). El morado de sus penitencias. El Comercio, a26.

Caretas [revista] (28 de octubre de 2004). Anuncio publicitario. Caretas, p. 15.

Carvalho, J. J. (2000). A religião como sistema simbólico. Uma atualização teórica. Série Antropologia, (285), 2-17.

Castagna, S. mons. (26 de septiembre de 1986). Inolvidable demostración de fe se generó con motivo del tercer aniversario del llamado 'fenómeno de la Virgen del Rosario'. El Norte, 8-9.

Centro de Difusión del Movimiento Mariano San Nicolás (CDMMSN) (1995). Libro de Mensajes. San Nicolás: CDMMSN.

Christian, W. ([1981] 1991). Religiosidad local en la España de Felipe II. Madrid: Nerea.

Colmenares, F. (1771). El día deseado. Relación de la solemnidad con que se estrenó la Iglesia del Santo Cristo de los Milagros. Lima: Oficina de la Calle San Jacinto.

Costilla, J. (2010). El milagro en la construcción del culto a Nuestra Señora de Copacabana (Virreinato del Perú 1582-1651). Estudios Atacameños. Arqueología y Antropología Surandinas, (39), 35-56.

Costilla, J. (2021). De milagros, imágenes y santuarios: apropiaciones simbólicas en tres cultos católicos sudamericanos. Revista Cultura y Religión, 15(2), 167-209. 
Costilla, J. (2011). El culto limeño al Señor de los Milagros (siglos XVII-XXI): fundamentos históricos para repensar una devoción mestiza. Revista Peruana de Historia Eclesiástica, (13), 169-204.

Costilla, J. (2013). El culto a la Virgen del Rosario en San Nicolás de los Arroyos (Argentina, 1983-2010): milagro y reconfiguración social. Runa, 34(2), 177-195.

Costilla, J. (2014). Luchas hermenéuticas, identidades y usos estratégicos del milagro en la elaboración y apropiación de cultos cristianos (siglos XVII a XXI- Perú, Bolivia y Argentina). (Tesis para optar al grado de doctora en Antropología), Facultad de Filosofía y Letras, Buenos Aires, Argentina.

Costilla, J. (2015). "Guarda y custodia" en la Ciudad de los Reyes: la construcción colectiva del culto al Señor de los Milagros (Lima, siglos XVII-XVIII). Fronteras de la Historia, 20(2), 152-179.

Costilla, J. (2016). Itinerarios antropológicos para una etnohistoria comparada de la religión. Diálogo Andino, (49), 299-309.

De la Calancha, A. ([1657] 1972). Crónicas agustinianas del Perú. Tomo I. Madrid: Consejo Superior de Investigaciones Científicas.

Díez Taboada, J. M. (1989). La significación de los santuarios. En C. Álvarez Santaló, M. J. Buxó y S. Rodríguez Becerra (coords.), La religiosidad popular. III (pp. 268-281). Barcelona: Anthropos.

Dirección General de Carabineros y Policías de Bolivia (1954). Orden General de Carabineros $n^{\circ}$ 2/54. La Paz, 5 de diciembre. Museo del Santuario de Copacabana, MS

Di Stéfano, R. y Zanatta, L. (2000). Historia de la Iglesia argentina: desde la conquista hasta fines del siglo XX. Buenos Aires: Mondadori.

Dri, R. (2012). Símbolos religiosos en la construcción de la identidad popular. En R. Dri (coord.), Símbolos y fetiches religiosos en la construcción de la identidad popular (pp. 13-33). Buenos Aires: Biblos.

Costilla, J. (2021). De milagros, imágenes y santuarios: apropiaciones simbólicas en tres cultos católicos sudamericanos. Revista Cultura y Religión, 15(2), 167-209. 
Durkheim, E. (1968 [1912]). Las formas elementales de la vida religiosa. Buenos Aires: Shapire.

Eliade, M. (1954). Tratado de historia de las religiones. Madrid: Instituto de Estudios Políticos.

Eliade, M. (1994). Imágenes y símbolos. Barcelona: Planeta-Agostini.

Elías, J. M. fr. (1981). Copacauana-Copacabana. Tarija: Santuario de Copacabana.

El Norte (25 de septiembre de 1993). Carpeta Virgen del Rosario de San Nicolás ( $N^{\circ}$ 682). Archivo Histórico Municipal de San Nicolás.

Estenssoro, S. (19 de mayo de 1925). Carta del Prefecto de La Paz al Obispo (18 de abril de 1925). La República, 1-11.

Estruch, D. (2017). El ejercicio del poder en el Jujuy colonial: enlaces y tensiones entre la jurisdicción civil y la eclesiástica: siglo XVI-XVIII. Buenos Aires: La Bicicleta Ediciones.

Ferro Medina, G. (2010). Guía de observación etnográfica y valoración cultural: santuarios y oficios. Apuntes, 23(1), 56-69.

Flores, F. C. (2011). ¿Turistas o peregrinos? Prácticas en torno al fenómeno religioso en San Nicolás de los Arroyos. Revista Transporte y Territorio, (5), 72-88. Fogelman, P. (2014). El cuerpo de la Virgen: discursos teológicos y representaciones históricas del cuerpo y la muerte de María. Cultura \& Religión, 8(2), 197-231.

Fogelman, P. (2013). Dos exvotos contra el Estado liberal: la Basílica y el libro de Salvaire sobre la historia del culto de Luján. En P. Fogelman, M. Ceva y C. Touris (eds.), El culto mariano en Luján y San Nicolás. Religiosidad e historia regional (pp. 25-50). Buenos Aires: Biblos.

Fraga, E. (2016). Performance ritual, construcción de la memoria, manipulación simbólica. Tras las huellas religiosas de los fenómenos políticos. Cultura \& Religión, 10(1), 49-65.

Costilla, J. (2021). De milagros, imágenes y santuarios: apropiaciones simbólicas en tres cultos católicos sudamericanos. Revista Cultura y Religión, 15(2), 167-209. 
Revista Cultura y Religión Vol. XV, 2021 № 2 (julio-diciembre)

"Fundador de Cruzada Pro-Copacabana reclama atención al Santuario paceño" (22 de agosto de 2010). El Diario. Recuperado de http://www.eldiario.net/noticias/2010/2010_08/nt100822/5_04nal.php

García Canclini, N. (2006). El consumo cultural: una propuesta teórica. En G. Sunkel (coord.), El consumo cultural en América Latina. Construcción teórica y líneas de investigación (pp. 72-95). Bogotá: Convenio Andrés Bello.

Geertz, C. (1987). La interpretación de las culturas. México: Gedisa.

González Torres, Y. 1982. Método comparativo en el estudio de las religiones. Anales de Antropología, 19(2), 107-121.

Hermandad del Señor de los Milagros de Nazarenas (2017). La Hermandad. Lima. [Consultado el 20 de junio de 2020]. http://www.hsmn..pe

Hervieu Léger, D. (2005). La religión, hilo de memoria. Barcelona: Herder.

Jacobo Albarrán, M. L. (2014). Religiosidad instituyente y corporalidad en la iconografía sagrada de los exvotos de San Juan de los Lagos. Cultura \& Religión, 8(2), 7-32.

Klaiber, J. L. (1996). La Iglesia en el Perú: su historia social desde la independencia. Lima: PUCP.

"La Cruzada Pro-Copacabana olvidada" (15 de julio de 2009). El Diario. Recuperado de http://www.eldiario.net/noticias/2009/2009_07/nt090715/1_04opn.php

Levaggi, C. (2007). La Virgen de San Nicolás, ¿símbolo popular posmoderno? En R. Dri (coord.), Símbolos y fetiches religiosos en la construcción de la identidad popular II (pp. 45-70). Buenos Aires: Biblos.

Manzanera, M. SJ. (3 de agosto de 2007). Virgen de Copacabana, Reina de Bolivia. El Diario, sección Opinión. Recuperado de http://www.eldiario.net/noticias/2007/2007_08/nt070803/1_03opn.php

Masferrer Kan, E. (2004). ¿Es del César o es de Dios? Un modelo antropológico del campo religioso. México: Plaza y Valdés.

Costilla, J. (2021). De milagros, imágenes y santuarios: apropiaciones simbólicas en tres cultos católicos sudamericanos. Revista Cultura y Religión, 15(2), 167-209. 
Nicoletti, M. A. (2012). La Patagonia como territorio en disputa: tensiones entre el Estado, la Iglesia y la Congregación Salesiana por el espacio misionero. Cultura \& Religión, 6(1), 183-203.

Pérez, C. (1984). Nota al señor Intendente solicitando la donación del terreno para el Santuario (San Nicolás, 21 de diciembre de 1984). [Transcripto en Pérez, 2007, 305 y ss.]

Pérez, C. (2007). Soy tu Madre. Visión testimonial del acontecimiento mariano. San Nicolás: CDMMSN.

Ramos Gavilán, A. ([1621] 1976). Historia de Nuestra Señora de Copacabana. La Paz: Universo.

Ricoeur, P. (1976). Introducción a la simbólica del mal. Buenos Aires: Megápolis.

Ricoeur, P. (1983). Freud: una interpretación de la cultura. México: Siglo XXI.

Rivero, C. (2008). Entre la "comunidad del acero" y la "comunidad de María". Un análisis antropológico sobre los avatares sociopolíticos en San Nicolás. Buenos Aires: Antropofagia.

Salles-Reese, V. (1997). From Viracocha to the Virgin of Copacabana. Austin: University of Texas.

Sánchez Rodríguez, S. (2002). Un Cristo Moreno “conquista" Lima: los arquitectos de la fama pública del Señor de los Milagros (1651-1771). En AA.VV., Etnicidad y discriminación racial en la historia del Perú (pp. 65-93). Lima: PUCP/IRA/Banco Mundial.

Santuario de Copacabana (2007a). Copacabana hoy. La Voz del Santuario de Copacabana, 2(6), 34-41.

Santuario de Copacabana (2007b). Copacabana en fechas. La Voz del Santuario de Copacabana, 2(6), 42-43.

Costilla, J. (2021). De milagros, imágenes y santuarios: apropiaciones simbólicas en tres cultos católicos sudamericanos. Revista Cultura y Religión, 15(2), 167-209. 
Revista Cultura y Religión Vol. XV, 2021 № 2 (julio-diciembre)

Santuario de Copacabana (2009). Mitología y ritos andinos en el santuario de Copacabana. La boca del sapo. La Voz del Santuario de Copacabana, 4(10), 33.

Schwarz, F. (2008). Mitos, ritos, símbolos. Antropología de lo Sagrado. Buenos Aires: Biblos.

Steil, C. A. (2002). Peregrinação e turismo religioso: Tendências e paradigmas de interpretação. Estudios sobre Religión. Newsletter de la Asociación de Cientistas Sociales de la Religión en el Mercosur, (13), 1-5.

Turner, V. W. (1969). The Ritual Process: Structure and Anti-Structure. Nueva York: Aldine Publishing Company.

Turner, V. W. (1980). La selva de los símbolos. Madrid: Siglo XXI.

Valda, E. (1992). Potosí y la Virgen de Copacabana. Francisco Tito Yupanqui, la Ch'ujlla y la Janaxkhacha. Potosí: Gratec.

Valda, E. (1999). La devoción a la Virgen de Copacabana en Esquiri y en la Villa Imperial de Potosí (siglos XVI-XX). Anuario de la Academia Boliviana de Histórica Eclesiástica, (5), 111-127.

Vásquez De Novoa, P. ([1766] 1868). Compendio histórico de la prodigiosa imagen del Santo Cristo de los Milagros. Lima: Imprenta de José María Concha.

Wright, P. (1998). Etnografía y existencia en la antropología de la religión. Sociedad y Religión, (16/17), 180-193.

Wright, P. (2015). "Yo tengo un don". Hermenéutica y antropología de la religión: entre la escucha y la sospecha de los símbolos. En J. M. Renold, (ed.), Religión: estudios antropológicos sobre sus problemáticas (pp. 65-86). Buenos Aires: Biblos.

Costilla, J. (2021). De milagros, imágenes y santuarios: apropiaciones simbólicas en tres cultos católicos sudamericanos. Revista Cultura y Religión, 15(2), 167-209. 